\title{
Negligence Without Fault $\dagger$
}

\author{
Albert A. Ehrenzweig*
}

[§ 1.] Four children chasing a kite drowned in a frozen pond. ${ }^{1}$ Damages were sought from a railroad company by whose admitted negligence water had been diverted to form the fatal pond. The Supreme Court of Pennsylvania denied hability because a prudent man in the defendant's place could not have "anticipated and foreseen this unfortunate happening" and because "there was no breach of duty to the children."2 Jury verdict, majority opinion, and dissent reflect the uncertainty and

$\dagger$ Copyright, 1951, The Regents of the University of California. Reprinted by permission. Section numbers contained in the original printing have been retained since internal references to them are made in the text. The section numbers have been placed in brackets to conform as nearly as possible to the normal publication form of the California Law Review. No other changes in the original text or footnotes have been inade, and consequently many footnotes are not in accord with the form prescribed by $A$ Uniform System of Citation (10th ed. 1958). As in the original text, footnotes for Parts I and II are numbered separately.

The Editors beheve it appropriate to reprint this work by Professor Ehrenzweig, since the original book has long been out of print and since once again controversy bas erupted over the proper bases of tort hability. Negligence Without Fault has been a significant contribution to the law and theory of tort liability, and its relevance has not been impaired by changes in some of the case law and umforn acts which it discusses. It is only fitting that an issue dedicated to Professor Ehrenzweig should make one of his most penetrating works available to a wider audience.

Some of the ideas suggested in Negligence Without Fault have been further developed in the author's later works. The reader's attention is particularly called to the following: TrEatISE on CONFutct of Laws ch. 6 (1962); Enterprise Liability Under "Foreseeable and Insurable Laws," 69 YaLE L.J. 595, 794, 978 (1960); "FuLL AID" INSURANCE FOR THE Trafmic Victim (1956); Psychoanalysis of Negligence, 47 Nw. U.L. Rev. 855 (1953).

*Dr. Jur., 1928, Vienna, Austria; J.D., 1941, University of Chicago; LL.M., 1942, J.S.D., 1952, Columbia University: Walter Perry Johnson Professor of Law, University of California, Berkeley; Honorarprofessor of Conflict of Laws, University of Vienna.

1 But for Professor E. W. Patterson's untiring advice and encouragement, this paper could not have been written. It seeks to establish a theory previously discussed by the writer in an unsigned Note, Loss-Shifting and Quasi-Negligence: A New Interpretation of the Palsgraf Case, 8 U. of Cㅍ․ L. Rev. 729 (1941) (cited as Loss-Shifting); in Soldiers Liability for Wrongs Committed on Duty, 30 CorN. L. Q. 179 (1944); and in two Studies prepared for the State of New York Law Revision Commission [Multiple Damages, Leg. Doc. (1944) No. 65 (J), and Products Liability, Leg. Doc. (1943) No. 65 (J) (cited as Products Liability)]; and further developed in Assurance Oblige-A Comparative Study, 15 LAw and Contear. Prob. 445 (1950) (cited as Assurance Oblige) [also Versicheruno aIs HaftUNGSGRUND, 72 JURtst. BiaetTer 253 (Vienna 1950); El Segutro Obliga, 3 Bor. DEL Inst. DE Der. Comp. DE Mextco 3 (1950)]. Much I owe to Dean Smith and Professor Llewellyn of the School of Law of Columbia University and to Dean Prosser of the School of Law at the University of California, Berkeley.

2 Irwin Savings \& Trust Co. v. Pa. R. R., 349 Pa. 278, 37 A. (2d) 432 (1944). For a note on cases dealing with similar fact situations, see 10 U. of PITTSBURGE L. REv. 97 (1948). Cf. infra note 62; Part II, notes 40, 143. 
hesitation prevailing in the allocation of the losses caused by the hazards of modern mechanical enterprise.

To create a balance between social and individual interests in this field has been the task and toil of the courts. Every year thousands of accidents foreseeably resulting from hazardous activities, seem to deniand full liability to the innocent victim. But the law, for the sake of social gain and progress, has limited that liability to one for a "negligence" measured by "proximate causation" and "duty of care." On the other hand, so greatly have these tests been blunted in their application to enterprise-defendants that their results are "little short of unanimity for the injured party." Jury verdicts are permitted to stand thougl supported by no more evidence than that of some kind of formal fault; plaintiffs are assisted by fictions and presumptions ( $\S 4)$; and liability insurance, devised for the mjurer's protection, has widely been adapted to secure the recovery of the injured ( $\S 6,11$ ). The Supreme Court itself, having greatly extended the neghgence liability of "Federal Enployers" (\$ 4), has been accused by a dissenting Justice of leaving the fault principle without much practical meaning. ${ }^{4} \mathrm{~A}$ new law of enterprise liability is in the making. To analyze this process in legal history, present theory and future probabilities both in legislative and judicial law making, is the purpose of this study.

The term "neghgence" implies blame for "neglect." The attempt will be made to show how and why the courts lave come to make this concept with its inherent censure $(\S \S 2,17)$ the basis and measure of compensation for harm caused by lawful activities ( $\S 3-8$ ); and what this has done to the concept and law of negligence ( $\$ \S 9-11$ ). A neghigence verdict condemning the substandard conduct of a drunken driver does not mean the same thing as a negligence verdict distributing losses caused by the lawful operation of a railroad corporation ( $\$ 12$ ). The resulting equivocations in the negligence rule may often lave proved valuable in promoting sound conpromise between competing policies. But if these equivocations are to continue as a vehicle of progress, they must be analyzed and recognized as such lest they hamper the organic growth of the law (§§ 12-17).

${ }^{3}$ GREEN, JUDGE AND JURX I39 (1930). For references to recent statistics see James, Functions of Judge and Jury in Negligence Cases, 58 YaLE L. J. 667, 687 (1949). See also Prosser, Proximate Cause in Califonia, 38 CALIF. I. Rev. 369, 397 (1950); McCord, Are You Your Brother's Keeper? [1950] Irs. I. J. 709 (1950).

4 Jackson, J., in Wilkerson v. McCarthy, 336 U.S. 53, 76, 69 Sup. Ct. 413, 424 (1949), where a railroad was held liable for neghigence to a switchman who had fallen into defendant's pit though posts and chains had been erected to prevent employees from entering the area. See also O'Donnell v. Elgin, J. \& E. R.R., 338 U.S. 384, 70 Sup. Ct. 200 (1949); Affolder v. New York, C. \& St. I. R.R., 339 U.S. 96, 70 Sup. Ct. 509 (1950) (liability under Federal Safety Appliances Act). 
Many crosscurrents and transitions make impossible an exhaustive classification of the liabilities now included in the "negligence" rule. But certain groups of those liabilities, being clearly related to "strict" liabilities ( $\$ 13-15)$, permit and indeed require a separate analysis and nomenclature. These groups of liabilities, after a brief discussion of their history and present crisis ( $\S 5-8$ ), will be analyzed as quasi-strict liabilities for "negligence without fault" ( $\$ 16)$. Elsewhere I suggested that this type of negligence be termed "quasi-negligence," as the basis of a non-fault liability within the framework of the traditional language of negligence. However, this terminology las been abandoned in this study to take account of the fact that we lave come to think of this "quasi-negligence" as of the negligence of our daily lives distinguishing therefrom as "gross," "wanton," or "wilful" negligence most of what remains of the original "moral" concept ( $\$ 23$ ).

Before the negligence rule ("the rule invoked"), as applied to enterprise liability, can be restated in terms of a 11ew "true" rule of "negligence without fault," that rule must be proved to be the "better rule" as to simplicity, clarity, and compatibility, as well as the "real rule" appearing in the "actual doing" of the courts. ${ }^{6}$ Thus, the new rule will liave to be tested as to damages, conflict of laws, pleading and jury practice; as to the several types of tortfeasors (imcluding employer and employee, automobile owner and operator, manufacturer and retailer, trustee and trust estate, government and official); and as to the several torts (including nuisance, deceit, libel, and breach of warranty). A brief outline of some results expected from sucl an investigation will be given at this time ( $\$ 17-23$ ).

Enterprise liability for negligence without fault las been promoted by, and has in turn promoted, the institution of liability insurance as a means of the injured's compensation. I attempted elsewliere to follow this development through several foreign legal systems. ${ }^{7}$ The next logical step in the protection of persons injured by liazardous activities would be the adoption of schemes of compulsory liability insurance. ${ }^{8}$ The opposition to such schemes is partly caused, I believe, by the failure to

5 Loss-Shifting, supra note 1, 736 n.38. This term abbreviates the awkward though more accurate phrase "quasi-strict liability for quasi-negligence." $C f$. the use of the terms "quasi-tort" in Wu, Two Forms of Tortious Liability in the Modern Chinese Law, THE ART of LAW 70 (1936); and "legal fault" in F. F. Stone, Touchslones of Tort Liability, 2 StAN. L. REV. 259, 283 (1950). Professor James approves the plurase "negligence without fault." James, Statutory Standards and Negligence in Accident Cases, 11 LA. L. REv. 95 (1950). For an earlier related analysis see Vold, The Functional Perspective for the Law of Torts, 14 NEв. L. BuLL. 217, 236 (1936).

${ }^{6}$ See Llewellyn, On Reading and Using the Newer Jurisprudence, 40 Cor. L. REv. 581, 608 (1940).

7 Assurance Oblige, supra note 1.

${ }^{8}$ See e.g., Grad, Recent Developments in Aulomobile Accident Compensation, 50 
segregate consciously an enterprise liability whose limits could be determined by its very insurability. It can only be a matter of conjecture, whether developments such as the "medical first payment revolution," which would secure certain benefits of automobile "liability insurance" to passengers and bystanders without regard to liability, or the "liability" insurance of immune tortfeasors $(\S \S 6,21)$, will initiate a semisocial "third party beneficiary insurance" which would distribute losses caused by hazardous enterprise without regard to the entrepreneur's liability.

The peculiarity of the present project which, to discover and promote trends, must presuppose much that miglit still be subject to controversy, may justify a somewliat unorthodox technique. In stating settled doctrine references to textbooks and law review articles have seemed more appropriate than citations of cases arbitrarily chosen from boundless accumulations. Living law is slown as it appears from encyclopedic case summaries and "business" literature, in a field in which case law has become so redundant that surveys of fact situations catering to the practitioner's needs have largely replaced the analysis of judicial opinion. Where, lowever, growing or future law is investigated, such analysis is indispensable to show characteristic divergences between rules avowedly and actually followed. For this purpose, to illustrate trends, views expressed in dissents, minority jurisdictions, and obiter dicta are as valuable as, or more valuable than, majority opinions purportedly following traditional doctrines. Similar considerations may justify the liberal use of quotations where language is our best guide to thougltt.

\section{I}

\section{THE RULE INVOKED: NEGLIGENCE}

\section{A. The Growth of the Rule}

\section{[§ 2.] 1. Preindustrial Period}

The history of tort law is determined by the search for a compromise between an "injurer's" law based on the injurer's conduct ${ }^{10}$ and an

Cor. L. REv. 300 (1950); Assurance Oblige, supra note 1, at 449; Note, Saskatchewan Automobile Accident Insurance Act [1950] Irs. L. J. 702 (1950); SHAwcross, THE LAW OF MOTOR INSURANCE (2d ed. 1949) 379; infra note 158.

9 See Yore, Automobile Medical Payments Coverage Points a New Way, Spectaror, Feb. 22, 1940. "First Aid Clauses" cover expenses for immediate surgical and medical aid to any third party, while so-called "medical indorsements" entitle occupants of the insured's car to medical expenses within specified limits. 8 Applearan, InsUrance Law AND PRACTICE \$§ 4895, 4896 (1942, Supp. 1949). This type of insurance seems to be spreading both to new types of accidents and new groups of persons. See 48 BEST'S No. 2, 45 (1947); Spectator, Feb. 14, 1946; James, Accident Liability Reconsidered: The Impact of Liability Insurance, 57 YaIE L.J. 565 (1948); James and Thornton, The Impact of Insurance on the Law of Torts, 15 LAW AND CONTEMPT. PROB. 431 (1950).

10 See Morris, Punitive Damages in Tort Cases, 44 Harv. L. Rev. 1173 (1931); Cooley, 
"injured's"11 law satisfying the injured..$^{12}$ Since the oldest tort law of vengeance implied blame, ${ }^{13}$ it punished fault; but it also protected the injured since it presumed fault even in the "misdeeds" of inanimate things. ${ }^{14}$ The injured's interests continued to prevail even when government sanction had replaced the feud, ${ }^{15}$ and even when refined psychological reflection and the powerful moral philosopliy of the Church had brought increased protection for the injurer by first making rebuttable and then abolishing the presumption of fault. ${ }^{10}$ The law of civil hability did "not so much regard the intent of the actor, as the loss and the damage of the party suffering." 17

True, at the end of the mineteenth century compromise seemed to have yielded to a general dogma of "no liability without fault." the idea of compensation for the injured, with little or no regard for the injurer's fault, had been preserved in many special rules such as those

Problems in Contributory Negligence, 89 U. of PA. I. REv. 335, 338 n.12 (1940). See in general Prosser, HANDBOOK OF THE LAW OF TORTS (hereinafter referred to as TORTS) 27 (1941).

11 These helpful terms, though not in general use, are listed in 5 MurRay, A NEw ENGitsh Dictionary on Historicas PrINCIPLES 301 (1901).

12 See e.g., Radin, A Speculative Inquiry into the Nature of Torts, 21 Tex. I. Rev. 697, 703 (1943); 1 STREeT, THE Foundations of Iegax Liabmity 477 (1906); Jenks, Theories of Tort in Modern Law, 19 L. Q. REv. 19 (1903); Takayanagi, Liability without Fault in the Modern Civil and Common Law, 16 Irx. L. REv. 163, 268; 17 IrL. I. Rev. 187, 416 (1921-1923); James, Accident Liability: Some Wartime Developments, 55 YaIE I. J. 365, 366 (1946); Lawson, Negrigence IN the CrvIn LAw (Oxford, 1950).

13 See HoLAmes, THE Comaron LAw 10 et seq. (1881). This psychological interpretation of absolute liability as a liability for "fault" could perhaps reconcile the seemingly inconsistent "absolute liability" theories [Wigmore, Responsibility for Tortious Acts: Its History, 3 Setect Essays no Anglo-American I.egat History 475 et seq. (1909), revised and brought up to date from 7 HARv. L. REv. 315, 383, 442 (1894)] and "fault" theories [Winfield, The Myth of Absolute Liability, 42 L. Q. REv. 37 (1926)] on the origin of tort law. See also Thayer, Liability without Fault, 29 HARv. I. REv. 810 (1916).

14 See Lass-Shifting, op. cit. supra note 1, 735 n.33; Hocares, op. cit. supra note 13, at 11. For a history of the "deodand," the noxal surrender of "guilty" things, see $i d$. at 7 et. seq.

${ }^{15}$ See Woodbine, The Origin of the Action of Trespass, 33 YALE I. J. 799 (1924); 34 YALE I. J. 343 (1925); Wigmore, op. cit. supra note 13, 504; Prosser, ToRTS 37, 77, 94; STREeT, op. cit. supra note 12, 77. See in general 1-SIMIPson and STONE, IAW aNd Soctery, Part I, chap. iv; Part II, chap. iii.

10 See Weaver v. Ward, Hob. 134, 80 Eng. Rep. 234 (1616). In criminal law the king's pardon brought relief in certain typical situations of "misadventure." See Moreland, A Rationale of Criminal Negligence, $32 \mathrm{Kx}$. L. J. 1, 127, 221, 3 n.6 (1943-1944). For a history of the fault requirement since Brown v. Kendall, 6 Cush. 292, 60 Mass. 292 (1850) see Wigmore, op. cit. supra note 13, $503 \mathrm{ff}$.

17 Lambert \& Olliot v. Bessey, T. Raym, 421, 422 (K. B. 1681).

18 See Ames, Law and Morale, 22 HaRv. L. Rev. 97, 99 (1908) ("The ethical standard of reasonable conduct has replaced the immoral standard of acting at one's peril"); Morris, Punitive Damages in Tort Cases, 44 HARv. I. Rev, 1173 (1931); Horares, op. cit. stlpra note 13, at 144; J. Smith, Tort and Absolute Liability, 30 HARv. Is. Rev. 241, 319, 409 (1917). 
concerning trespass to land and conversion, or liabilities for animals and dangerous things and of insane persons; ${ }^{19}$ and instances of such liabilities continued to be added by new interpretations of ancient common law (explosives and blasting, "breach of warranty") ${ }^{20}$ as well as by modern legislation (workmen's compensation). Moreover, at the very time the fault dogma seemed to have reached its climax, it liad been made to serve the injured's protection in many ways: Although fault was to be a condition of recovery, such fault was again presumed, ${ }^{21}$ and causation "spoke for itself." Fault was seen where, innocent as the "wrongdoer" might have been, a "reasonable inan" would have acted differently;" and under the principle of "respondeat superior" another's fault could be a basis of liability. ${ }^{24}$ No wonder then that this law of an "emasculated," "Iegal," or "objective" fault, ${ }^{25}$ though rationalized in a language of "social" morahty, ${ }^{26}$ soon found a new interpretation.

As late as 1898 Lord Herschell considered all legal sanctions as designed to deter. ${ }^{27}$ But now the "unreasonable man" is seen as acting

10 Representative cases are: Perry v. Jefferies, 61 S. C. 292, 39 S. E. 515 (1901) (trespass); Hyde v. Noble, 13 N. H. 494, 38 Am. Dec. 508 (1843) (conversion); McKee v. Trisler, 311 IIl. 536, 143 N.E. 69 (1924) and Brackenborough v. Spalding U. D. C., L. R. [1942] A. C. 310 (animals); Rylands v. Fletcher, infra $\$ \S 13,20$ (dangerous things); Davis v. Niagara Falls Tower Co., 171 N. Y. 336, 64 N. E. 4 (1902) (nuisance); Williams v. Hays, 143 N. Y. 442,38 N. E. 449 (1894), 157 N. Y. 541,52 N. E. 589 (1899) (insane and infants); Van Vooren v. Cook, 273 App. Div. 88, 75 N. Y. S. (2d) 362 (4th Dept. 1947) (insane). In general see PROSSER, TORTS 428, 432, 443, 446, 1085, 1089; James, supra note 12, 366 ff.; infra. \$§ 3, 8, 20.

20 See Hay v. Cohoes Co., 2 N.Y. 159, 51 Am. Dec. 279 (1849) (blasting); Products Liability, supra note 1, passim; Ultramares Corp. v. Touche, 255 N.Y. 170, 174 N. E. 441 (1931) ("deceit" by accountants' advice); Coffey v. Midland Broadcasting Co., 8 F. Supp. 889 (D. C. W. D. Mo. 1934) (radio defamation).

${ }^{21}$ See J. Smith, Surviving Fictions, 27 YaIE L. J. 147 (1917); Bohlen, The Effect of Rebuttable Presumptions of Law upon the Burden of Proof, 68 U. OF PA. L. REv. 307 (1920); Harris, Liability without Fault, 6 TULANe L. Rev. 337, 338 (1932). For a natural law justification of this presumption see Thomasios, Fundasmenta JuRIs Naturae eT GENTIUM, I, 10 (1728) who advocates the presumption of fault, "because injuries are frequently inflicted by fault and the law should fit what inost frequently happens." For the presumption of fault in modern Continental law see the writer's TORT LIABIIIT FOR FAULT (Schuld Haftung im SchadentersatzRechi) (Manz, Vienna: 1936) 34, 42, 53, 66, 69, 182, 184, 187, 233.

22 See infra § 3 ,

23 See infra $\$ 9$.

24 See Y. B. Smith, Frolic and Detour, 23 Cor. L. REv. 444, 458 (1923); Seavey, Speculations as to "Respondeat Superior," HaRvard LEGAL EsSAYS 433 (1934) and infra \& 4.

${ }^{25}$ See infra $\$ \S 9,17$. Seavey, supra note 20, 439 contrasts the "legal fault" of civil hability with the "moral fault" of criminal responsibility. But see Ames, supra note 18.

26 See Restatearent, Torts \& 282, comment 3 (1934); Prosser, Torts 18, 426.

27 Allen v. Flood [1898] A.C. 1, 131. Cf. Street, op. cit. supra note 12, 478 n.4: "This looks very much like an effort to give an appearance of modern refinement to a crude mstinct which nevertheless is one of the mainsprings of human action in all stages of society." See also, Sacdrond, Law of TorTs 13, 18 (10th ed. 1945). 
"at his peril,"28 usually without regard to ideas of punishment or deterrence. $^{29}$ And Section 519 of the Torts "Restatement" of the American Law Institute would impose liability for the "unpreventable miscarriage" of "ultrahazardous" activities. ${ }^{30}$ If this be the trend today, the courts, at least in their language, lave failed to concede the change, since the rules of enterprise hability are still couched in terms which imply repreliensible conduct. This fact lias, on the one hand, helped to preserve the essentially admonitory institution of punitive damages ${ }^{31}$ and, on the other hand, tended to revive the injurer's protection by producing the doctrines of proximate causation, breacl of duty, and contributory negligence. ${ }^{32}$ The same rationale lias given new incentive to the struggle against the liability of the substandard $\operatorname{man}^{33}$ and of the insane; ${ }^{84}$ has encouraged the proposals for contribution between tortfeasors; ${ }^{35}$ and has caused the recognition of "degrees" of fault and fault liability which probably play a much larger part than is usually supposed. ${ }^{36}$

Why is it that this struggle between an injurer's and an injured's law of torts has, up to the present time, been fought within a law of fault

\footnotetext{
28 Holmes, op. cit. supra note 13, 51 .

29 See Prosser, TORTS 11.

80 See infra $\$ 14$.

31 See Morris, supra note 18, 1176 et seq.; and the writer's study on "Multiple Damages," supra note 1.

32 Butterfield v. Forrester (K. B. 1809) 11 East 60, 103 Eng. Rep. 926. This defense was in turn limited in the injured's favor by the doctrines of "Iast clear chance" [Davies $v$. Mann (Exch. 1842) 10 M. \& W. 546, 152 Eng. Rep. 588], "absolute nuisance" [Beckwith v. Stratford, 129 Conn. 506, 29 A. (2d) 775 (1942)] and "wilful and wanton conduct" [Karanovich v. George, $348 \mathrm{~Pa}$. 199, $34 \mathrm{~A}$. (2d) 523 (1943)].

83 See Seavey, Negligence-Subjective or Objective?, 41 HARv. L. REv. 1 (1927); MoreIand, supra note 16, 172; Prosser, Torts 224 and cases cited; Note, $8 \mathrm{U}$. of Pitrsburor L. REv. 274 (1942) (blind persons). On the converse situntion in the expert's liability see e.g., Swan, The California Law of Malpractice of Physicians, Surgeons, and Dentists, 33 Curm. L. REv. 248, 252 (1945).

34 See, e.g., Williams v. Hays, supra note 19; Hornblower, Insanity and the Law of Negligence, 5 Cos. L. REv. 278, 284 (1905). For foreign laws see Takayanagi, supra note 12, 16 Irr. t. REv. 299 ff.

35 See James, supra note 12, 377 .

${ }^{86}$ Bauer, The Degree of Moral Fault as Affecting Defendant's Liability, 81 U. of PA. L. REv. 586 (1933). See also Bauer, The Degree of Defendant's Foult as Affecting the Administration of the Law of Excessive Compensatory Damages, 82 U. of PA. L. REv. 583 (1934). The separate treatment of "gross negligence" in various fields [see e.g., Eliott, Degrees of Negligence, 6 So. CaL. L. Rev. 91, 127 (1933)] can be traced back to the civil law doctrine. See Coggs v. Bernard, 2 Ld. Raym. 909, 92 Eng. Rep. 107 (1703). See also F. Green, High Care and Gross Negligence, 23 Irr. L. REv. 4 (1928). For the Continental law see Takayanagi, supra note 12, 16 IrI. L. REv. 166; EHRENZWEIG, op. cit. stipra note 21, at 203 et seq. The vitality of Continental tort law in present-day Louisiana is stressed by F. F. Stone, Tort Doctrine in Louisiana: The Materials for the Decision of a Case, 17 TULANE L. REv. 159 (1942). See in general Green, Illinois Negligence Law, 39 IIL. I. REv. 36, 116, 197; 40 IrL. I. REv. 1, 47 (1944-1945).
} 
liability? The fact that civil liability was long part of the criminal law, which from early times has relied upon a theory of punishment for fault, does not offer a sufficient explanation because civil liability failed to discard the fault theory even after its emancipation from the criminal law; ${ }^{37}$ nor do the influence of the Rounan law or of the moral philosophy of the Clurch account, by themselves, for the preservation of that theory; ${ }^{38}$ or the "natural law" doctrine whose "eternal principles" have always equally supported both a theory of fault liability and the opposite postulate "that the damage which we have inflicted on others must be made good." ${ }^{39}$ Rather, the fault theory has been maintained, I beheve, as the governing theory of tort law because the only alternative lias too often been seen in a rule of unrestricted liability for all causation. Such a rule would not only be impracticable but could be rationalized only by the paradoxical argument that the innocent injured is "still more innocent than the innocent injurer," which has found a peculiar expression in Sections 403 and 404 of the Soviet Civil Code. ${ }^{41}$ The attempt will be made in this study to show that a strict liability for all causation is not the only alternative, but that fault liability for liarm foreseeably caused by reprehensible conduct can be, and as to enterprise risks has largely been, replaced by a liability for "negligence without fault" for harm typically caused by lawful conduct.

\section{The Industrial Revolution}

[§ 3.] a. Harm unavoidably caused by lawful enterprise. The negligence rule rebels. By an ironical turn of legal history the appearance and judicial recognition of meclianical enterprise as a new source of risks and losses lias not only failed to produce a new principle of civil liability, but has actually played the decisive part in perfecting the fault dogma. ${ }^{42}$ It is with

${ }^{87}$ See 1 Stat. 556, 5 \& 6 W. \& M., c. 12 (1694), an Act to take away the process for the Capiatur fine in the several courts at Westminster. PoILOCK, TORTS (14th ed., 1939) 455 n.d.; Prosser, TORIs 14 et seq. On the relation between criminal and civil negligence see Moreland, supra note 16, 127; Morris, The Role of Criminal Statutes in Negligence Actions, 49 Cor. I. Rev. 21 (1949).

38 See Harris, Liability without Fanlt, 6 TULANE L. Rev. 337, 349 (1932). On the history of Roman and Greek law, Radin, supra note 12, at 703.

39 Larva Legis Aquiliae Detracta Actioni de Damino Dato Receptae in Forus Gerzranorum by Garus Mathelas Arend "preside Thomasio" (1743) 4. See also Thomasios, Fundamenta Juris Naturae ex Gentrom (1728) 17 \& 46 . In general see Isaacs, Fault and Liability, Two Views of Legal Development, 31 HARv. L. REv. 954 (1918).

40 For a history and criticism of this "paradoxon" see UNGER, HANDELN AUE EIGENE Gefatro (Acting at One's Perti) (1904).

41 These sections impose liability for causation while permitting proof of unavoidability. See 1 GsovsKr, SovIET CIvIL LAW 489 (1948); Assurance Oblige, supre note 1, at 448.

42 See WINFIEID, LAW OF TORT (3d ed., 1946) 391; Winfield, The History of Negligence in the Law of Torts, 42 L. Q. Rev. 184, 195 (1926) ("Perlaps one of the chief agencies in 
the appearance and recognition of the new risks of mechanical enterprise, that "No liability without fault" came to claim general validity. Whatever protection the injured has since achieved has been developed within legal rules couched in terms of censure for the "negligent" injurer. While this result may, if clearly realized, represent a desirable compromise, the fact that it has been concealed behind a nondiscriminating terminology has, I believe, created many of the problems and conflicts of our modern tort law.

Transportation by railroads was among the first risks of mechanical enterprise which demanded and produced a liability stricter than that for reprehensible conduct. Railroad liability to shippers for the safety of their goods fell easily into the pattern of the age-old strict liability of common carriers. ${ }^{43}$ But the liability of railroads to their passengers has always been governed by the negligence rule previously applied to the carriage of passengers by coacl. ${ }^{44}$ This failure of the courts to extend strict liability to passengers may have been due to the fact that the rationale of the common carriers' liability ${ }^{45}$ seemed inapplicable; that at that time all strict liabilities were considered as the remnants of a barbarous age; ${ }^{40}$ and that limitation of liability was favored by the Roman law ${ }^{47}$ and the economic doctrine of laissez faire, ${ }^{48}$ as well as by the desire to encourage

the growth of the idea is industrial machinery."). See also Green, The Duty Problem in Negligence Cases, 29 Cor. L. Rev. 255, 260 (1929); Seavey, supra note 24, 439; Marceau, Reflections on the Theory of Neglizence, 5 LA. L. Rev. 495, 496 (1944). Prosser, TorTs $26, \mathrm{n} .31$, reports that out of 279 Minnesota cases on proximate cause, only 33 had not concerned defendants "who by means of rates, prices, taxes or insurance are best able to distribute to the public at large the risks and losses which are inevitable in a complex civilization."

43 See 2 Kent, Comonentaries 602 (2d ed., 1832).

44 See Aston v. Heaven, 2 Esp. 533, 170 Eng. Rep. 445 (1797). Jonzs, EssAy on the Law of BAmMENTS (first published in 1796) mentions passenger claims for the first time in the 1836 edition. See also Crofts v. Waterhouse, 3 Bing 319, 130 Eng. Rep. 536 (1825); Ingalls v. Bills, 9 Metc. 1 (Mass. 1845). For a discussion of this "amazing" result see Ray, NegLIgence of Imtrosed Dutres, Comamon Carruers 22 (1893). See also Bohlen, Fifty Years of Torts, 50 Harv. L. Rev. 725, 727 (1937) ; Ballantine, A Compensation Plan for Railway Accident Claims, 29 HARv. L. REv. 705, 706 (1916).

45 That hability was thought to be founded upon a custom designed to prevent carriers' frauds, and upon the consideration that "they can protect themselves" (Aston v. Heaven, supra note 44, at 535, 170 Eng. Rep. at 446), while manimate property could not [Camden \& Amboy R.R. v. Burke, 13 Wend. 611,618 (N. Y. 1835)]. See also Christie v. Griggs, 2 Campb. 79, 170 Eng. Rep. 1088 (1809).

40 See Camden \& Amboy R.R. v. Burke, supra note 45 at 623 ; J. Smith, Tort and Absolute Liability一Suggested Changes in Classification, 30 HARv. L. REv. 241, 319, 409 (1917).

47 The Roman law (as taught by Pothier in his Pandects) had greatly influenced Jones, Story, and Kent, the principal authorities referred to in the early liability cases. See Camden \& Amboy R.R. v. Burke, supra note 45, at 625; KENT, op. cit. supra note 43, at 598. 48 "Let the loss rest where it falls" seems to have been the creed of the era, also 
industrial enterprise. ${ }^{49}$ Similar reasons have probably determined the adoption of the fault theory for other enterprise liabilities.

A development towards a stricter liability cannot be observed until the second half of the nineteenth century. That development was apparently due to a certain sentiment of hostility against innovations caused by the increase of industrial risks and financial failures; to the humanitarian demand for broader protection in a more social minded era; and finally to the fact that the growing industrial wealth and stability, coupled with a spreading system of liability insurance, ${ }^{50}$ made it easier to dispense with the injurer's protection afforded by a liability law primarily based on fault. It became nore and more apparent that it was "socially expedient to spread and distribute throughout the community the inevitable losses."

Here and there, this tendency has led to the enactment of strict liability statutes ${ }^{52}$ and to stillborn theories such as that of the new liability for "ultrahazardous activities." developed within the law of negligence liability, where it could not fail to transform substantially the concepts of negligence as reprehensible conduct and of negligent causation as causation of foreseeable and

expressed in the caveat emptor of contract law [see Hamilton, The Ancient Maxim Caveat Emptor, 40 YaLE L. J. 1133 (1931); Llewellyn, On Warranty of Quality and Society, 36 Cor. L. Rev. 699 (1936) and 37 Cor. L. REv. 341 (1937)], and in the fellow-servant rule in the law of torts [see Farwell v. Boston \& Worcester R.R., 4 Metc. 49, 38 Am. Dec. 339 (Mass. 1842)].

49 This spirit was still alive in Bohlen's criticism of the Rylands $v$. Fletcher rule [Bohlen, The Rule in Rylands v. Fletcher, 59 U. oF PA. L. Rev. 298, 373, 423 (1911)] as well as in earlier aircraft cases [e.g., Herndon v. Gregory, 190 Ark. 702, 81 S.W. (2d) 849 (1935) ]. But $c f$. Molloy, Fletcher v. Rylands, a Reëxamination of Juristic Origins, 9 U. oF CEr. L. Rev. 266 (1942); Prosser, Nuisance Without Fault, 20 TeX. L. Rev. 399 (1942); infra $\S 20$.

50 See infra $\$ 11$.

51 X. B. Smith, supra note 24,457 (with reference to employee claims). See also, e.g., Feezer, Social Justice in the Field of Torts, 11 MnN. L. Rev. 313 (1927); Feezer, Capacity to Bear Loss as a Factor in the Decision of Certain Types of Tort Cases, 78 U. OF PA. L. REv. 805 (1930); Assurance Oblige, supra note 1, at 446.

52 See e.g., the Uniform Aeronautics Act, 11 U.L.A. 159 (1938) adopted in at least 20 states. See in general Takayanagi, supra note 12, 270 et seq. On the Continent of Europe legal writers have long demanded the recognition of a general principle of liability for hazardous activities [see, e.g., RANDA, DIE SCBADENERSATzPFIICET (2d ed. 1908)]; and statutes have adopted this hability for specific "dangerous enterprises" such as railroads, automobiles, aircraft, and suppliers of electricity. In a significant decision (Sept. 10, 1947, $1 \mathrm{Ob} 500 / 47$ ) the Supreme Court of Austria has used such statutes to establish a doctrine of respondeat superior (otherwise foreign to Continental law) for hazardous activities. See Fenzl, Erfolgshaftung der "Gefaehrlichen Betriebe," 3 OESTERREICHISCHE JURISTENzETrONG 362 (1948).

${ }^{53}$ See Rest. Torts, \& 519; Comment, Absolute Liability for Ultrahazardous Activities: An Appraisal of the Restatement Doctrine, 37 CALIF. L. REv. 269 (1949) with further references. 
avoidable harm. ${ }^{54}$ For neither the entrepreneur's lawful activity itself nor the individual causative act satisfies both requirements. A hazardous activity cannot be penalized as "reprehensible" if lawful; and the harm caused in the course of that lawful activity is not "avoidable" if calculated as unavoidable at the start of that activity. ${ }^{\text {s5 }}$

Continental laws have sought to overcome similar difficulties by presumptions of fault..$^{56}$ "Where one would not or could not change the substantive law, the procedural law was used and the victim was assisted by ... a presumption of fault." ${ }^{\prime 37}$ American law, whose pioneer spirit was probably opposed to thus stigmatizing growing enterprise, has reached similar results by adopting two rules which have hidden the subservience to the needs of our era belind foreign words simulating ancient origin. [§4.] b. Respondeat superior and res ipsa loquitur. The rule is conquered. A man was killed in a house by gas escaping from a leak in a gas main more than 400 feet away. Judge, jury, and plaintiff will be reluctant to hold for this accident, which was of a type calculable and calculated as an unavoidable incident of the employer's enterprise, the laborer who had "neghigently" encased the leaking main almost one year earlier. But, says the law, let the master answer for the servant: Respondeat superior. ${ }^{58}$ And if we have difficulty in finding fault with the servant, let the thing speak for itself: Res ipsa loquitur..$^{59}$ Let the thing help the victim in

54 See infra $\$ 9$.

55 Similar problems have arisen for similar reasons under laws which, though excusing trespass in emergency, impose damages on the trespasser. See the writer's IRRTUM UND RECHTSWDRIGKEIT (Mistake and Unlawfulness) 21 (Vienna: 1931) ; infra Part II note 38.

56 See Harris, supra note 38, 337 et seq.; Loss-Shifting 735; MaIorCA, Probuenc Detia Responsabinita' Civne (1936); Releinstein, The Law of Torts, Cases and Materints

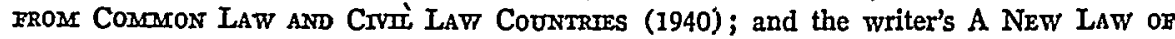
TORTS (ZUR ERNEUERUNG des SchadenERSATZREchtes) (1937).

57 Société des Nations, Institut International de Rone pour l'Unification du Droit Privé, Responsabilité Civile des Automobilistes, Etude Préliminaire 14 (1935) (transl.).

58 For a discussion of the function of this doctrine in the development of enterprise liability see Holmes, Agency, 4 HARv. L. Rev. 345 (1891); Y. B. Smith, sthpra note 24, 460; Note, Vicarious Liability: Statutes as a Guide to its Basis, 45 Harv. L. REv. 171 (1931); Steffen, Independent Contractor and the Good Life, 2 U. oF CHI. L. REv. 501, 507 (1935); Prosser, Torts 472. Neuner, Respondeat Superior in the Light of Comparative Law, 4 LA. L. REv. 1 (1941) describes the parallel development of the German law which, though clearly requiring fault (in selection or control) for vicarious liability, comes very close to the strict liability of Anglo-American and French law. See also supra note 52; Radin, supra note 12, 707. The law of Louisiana stands between the two legal systems. See Miller, The Master-Servant Concept and Judge-Made Law, 1 LoyouA L. REv, 25 (1941). The law of parental liability [see Spence, Parental Liability, [1948] INs. L. J. 787 (1948)] and the "family car doctrine" [James, supra note 9, 564] offer interesting analogies. See infra $\S 20$. See also Ferson, Bases for Master's Liability and for Principal's Liability to Third Persons, 4 VAND. L. REV. 260, 263 (1951).

59 For history, rationale, and principal applieations of this doctrine, as well as for further references see Prosser, ToRTs 293, and Prosser, Res Ipsa Loquitur in California, 37 Carne. L. Rev. 183 (1949). See also Note, 47 Cor. I. REv. 850 (1947). 
proving that something has occurred in the master's hazardous activities that can justly be imputed to the master. If we may trust hesitant beginnings, the thing may yet come to stand by itself for such proof. ${ }^{60}$

By two bold strokes, negligence liability has thus been enabled to distribute the losses caused by modern enterprise. But the resulting strict hability, having preserved the language and himitations of the law of negligence, lacks a rationale. This negligence liability is not liability for avoidable causation by reprehensible conduct of foreseeable harm. True, respondeat superior, too, though rendering hable a nonnegligent employer, purports to be based on negligent causation requiring foreseeability of harm. But could the laborer who encased the leaking gas main, or any reasonable man in his place, in that split second of inattentiveness in which he committed his technical error, in any real sense foresee harm such as the stranger's death one year later? If foreseeability is understood as a psychological reality rather than a legal fiction, a negative answer seems obvious; and yet the higliest court of New York held the laborer's employer for neghigence. ${ }^{61}$ True, respondeat superior too, though creating a liability for hann arismg from lawful activities, purports to be based on reprehensible conduct. But was the children's drowning in the frozen pond reprehensibly caused by that (unidentified and perhaps unidentifiable) foreman for whose action we want to hold the railroad? A negative answer seems obvious, and yet a jury found negligence, a trial court assessed damages and two appellate judges agreed. ${ }^{62}$ Perhaps it is significant for the imperceptible shift of the negligence concept from reprehensible causative conduct to lawful enterprise activity that in both cases the court, unwillingly perhaps, spoke of the "defendant's" foresiglit rather than that of its employee.

The Supreme Court of the United States, in a long line of cases under the Federal Employers Liability $\mathrm{Act}^{\mathbf{6}}$ has permitted jury verdicts against railroads for common law negligence to stand in the absence of such reprehensible conduct or foreseeable harm as would probably have been required against non-enterprise defendants-as in the case of the switchman who fell into defendant's pit, though posts and chains had been erected to prevent employees from entering the area. ${ }^{64} \mathrm{Mr}$. Justice Frank-

60 See infra $\$ 8$ at note 128.

61 See Ehret v. Village of Scarsdale, 269 N. Y. 198, 199 N. E. 56 (1935).

62 Irwin Savings \& Trust Co. v. Pa. R. R., supra note 2.

63 See the summary of these cases in Justice Douglas' concurring opinion in Wilkerson v. McCarthy, 336 U. S. 53, 68, 69 Sup. Ct. 413, 420 (1949).

64 Wilkerson v. McCarthy, supra note 63. See also, e.g., Anderson v. Atchison, T. \& S. F. R. R., 333 U.S. 821, 68 Sup. Ct. 854 (1948) (conductor dying from injuries after having fallen off the train-no allegation that crew knew of fall or injuries or that fall caused by defendant's negligence); Urie v. Thompson, 337 U. S. 163, 69 Sup. Ct. 1018 (1949) (occupational disease); supra note 4. 
furter states that the difficulties in these cases derive "largely from the outmoded concept of 'negligence' as a working principle for the adjustments of injuries inevitable under the technological circumstances of modern industry." mode of dealing with industrial injuries," mately be replaced by statute. But much of the present confusion can probably be removed by reahizing that the law of negligence as applied in this field has undergone a fundamental change in its constituent concepts of the "reasonable man" and his "foresight." Before a general analysis of this problem can be made, a brief survey of the fields of its appearance seems in order.

\section{Some "Negligent" Entrepreneurs}

[§ 5.] (a.) Transportation, utilities, and entertainment. In the law of railroad liability to passengers various devices have been used from the beginning to promote a stricter liability. Early courts, in order to be able to hold a railroad for injuries caused by a defective axle, treated the manufacturer as the railroad's "agent" and borrowed a theory of "warranty of roadworthiness" from the law of the sea. ${ }^{67}$ The later development, however, was entirely based on a theory of respondeat superior for negligence. Indeed, "the law of negligence of the late mineteenth century was to a considerable extent the law of railway accidents." growth of railroad liability under this doctrine can be followed through the several editions of Story's famous texthook on bailments. The first edition (1832) declares it as "certain" that carriers with regard to their passengers "are bound only to due care and diligence in the performance of their duty." ${ }^{\prime 69}$ The third edition (1843), citing the first railroad cases, adds that "of course" carriers are responsible "for any, even the slightest neglect," and introduces a presumption of fault. ${ }^{70}$ The sixth edition (1856)

${ }^{65}$ Wilkerson v. McCarthy, supre note 63 , at 65,69 Sup. Ct. at 419 . See also Mr. Justice Frankfurter's concurring opinion in Urie v. Thompson, supra note 64 at 196, 69 Sup. Ct. at 1038 .

68 Wilkerson v. McCarthy, supra note 63 at 65,69 Sup. Ct. at 419.

07 Hegeman v. Western R. R., 3 Kernan (13 N.Y.) 9, 22 (1855). Accord: Alden v. N. Y. C. R. R., 26 N. Y. 102, 104 (1862), stressing the advantage of the certainty of this "hard rule" over the "trouble and expense of a strongly litigated contest before juries." But of. McPadden v. N. Y. C. R. R., 44 N. Y. 478 (1871). On the doctrine of seaworthiness see the excellent Note, 34 CoRN. L. Q. 92 (1948).

68 Prosser, Res Ipsa. Loquitur in California, 37 CaLr. L. REv. 183, 186 (1949).

69 Story, Conomentaries on the Law of Bandandis 378 (1832).

$70 \mathrm{Id}$. (3d ed., 1843) at 592: "For the law will ... in tenderness to human life and luman limbs, hold the proprietors liable for the slightest negligence, and will compel them to repel, by satisfactory proofs, every imputation thereof" (at 593). A significant phase of the development of railroad liability in Illinois is described by Green, supra note 36, 39 In工. L. Rev. 36, 42 et seq. 
is the first one expressly to discuss railroad liability and, significantly enough, the first one to talk in terms of risk and public policy: "When carriers undertake to convey persons by the powerful but dangerous agency of steam, public policy and safety require that they be held to the greatest possible care and diligence. " 71 In conjunction with this rule, the railroad's burden of proof has carried the railroad's stricter liability into many other fields of the law of torts," by "cross-breeding" with the rule of res ipsa loquitur in its original meaning as a rule of evidence. ${ }^{73}$

In the law of automobile liability, as in the law of railroad liability, an inherently dangerous activity was made lawful because of a prevailing social interest. "4 Early attempts to subject the "devil wagon" to the rule applying to "ferocious amimals"75 failed, apparently because such strict liability had never been establisled for railroads. But here, as in the law of railroads, the application of negligence liability to the inevitable results of a lawful activity lias deprived the negligence test of its original meaning; the foresight of the reasonable man, with or without the lielp of res ipsa, lias come to be applied to innocent, and even to involuntary, acts. ${ }^{78}$ And the "family car" doctrine or owners' liability statutes ${ }^{77}$ lave effected shifts similar to those effected by the doctrine of respondeat superior in other fields of enterprise liability.

The liability of air carriers, after a start in the direction of an absolute

71 SroRx, 0p. cit. supra note 69, at 607, quoting from Pha. and Reading R. R. v. Derby, 14 How. (55 U.S.) 468, 486 (1852). Significant summaries of railroad cases are now currently published in the NACCA LAw JourNaI. See, e.g., vol. 1, at 153 and vol. 2, at 245 .

72 See Scott v. London \& St. Katherine Docks Co., 3 H. \& C. 596, 601, 159 Eng. Rep. 665,667 (1865); Prosser, supra note 68 at 184.

73 See Prosser, supra note 68 at $186,187$.

74 To use Terry's terminology, a "negligent conduct" ceased to be a "negligent wrong" because of the "necessity of the risk." See infra \$ 20.

75 Lewis v. Amorous, 3 Ga. App. 50, 55, 59 S. E. 338, 340 (1907). In 1904 we read complaints about "wealthy hoodlums" with their "devil wagons." Note, 59 CENT. L. J. 432 (1904). In 1909 an automobile was declared to be "nearly as deadly as, and much more dangerous than, a street car or even a railroad car" [Weil v. Kreutzer, 134 Ky. 563, 567, 121 S. W. 471, 472 (1909)]; and as late as 1920, the Florida court treated the automobile as a dangerous instrumentality rendering the owner liable whenever negligently used [Southern Cotton Oil Co. v. Anderson, $80 \mathrm{Fla} .441,86$ So. 629 (1920)]. See also ProssER, TORTs 500; James, supra note 9, 564; Blakemore, Is the Law Fair to the Motor Vehicle? 65 U.S.L. REv. 20 (1931); Nixon, Changing Rules of Liability in Automobile Accident Litigation, 3 LAw \& Conteacr. Prob. 476 (1936).

76 See Loss-Shifting, supra note 1, 739; Bowers, Selected Articles on Conmplsory Insurance 36 (1929); Frence, The Automobile Compensation Pran 46 (1933); SpILrent, Le Contrat D'Assurance de Responsabiltí Civme (1934) 11, 18; Nixon, supra note 75, 477 ("fractional mistake in management"); Barret, Mechanics of Control and Lookout in Automobile Law, 14 Tutane L. Rev. 493 (1940). The Insurance Law Jouranat publishes currently significant automobile cases.

77 See James, supra note 9, 564; infra § 20. 
liability similar to that for ferocious animals and explosives, ${ }^{78}$ has apparently returned to the general negligence rule and its problems. ${ }^{70}$ Here, too, the doctrine of res ipsa loquitur may yet become the vehicle of a stricter liability, ${ }^{80}$ unless occasional deviations from negligence language foreshadow the beginnings of a more articulate theory of risk distribution. ${ }^{81}$ The Warsaw Convention ${ }^{82}$ and suggestions for similar federal and uniform state legislation ${ }^{83}$ seem to point towards the adoption of non-fault compensation schemes. Corresponding developments can be observed in the liability of suppliers of telephone and telegraph service, of electricity ${ }^{84}$ and of oil and gas. ${ }^{85}$ And there seems to be a definite trend toward an increased "fault" liability of public entertainers ${ }^{80}$ and innkeepers. ${ }^{87}$

78 Guille v. Swan, 19 Johns. 381,10 Am. Dec. 234 (N.Y. 1822) (forced landing in private garden); Canney v. Rochester Agricultural and Mechanical Ass'n, 76 N. H. 60, 79 Atl. 517 (1911) (falling balloon). Cf. MCNAIR, THE LAW OF THE Air (1932); Kingsley and Bates, Liability to Persons and Property on the Ground, 4 J. OF ATR L. 515 (1933).

79 Richmond \& M. Ry. Co. v. Moore, 94 Va. 493, 27 S. E. 70 (1897); Peckett v. Bergen Beach Co., 44 App. Div. 559, 60 N. Y. Supp. 966 (1899); Roper v. Ulster Co. Agric. Soc., 136 App. Div. 97, 120 N. Y. Supp. 644 (1909); Platt v. Erie Co. Agric. Soc., 164 App. Div. 99, 149 N. Y. Supp. 520 (1914). For further references see Bohlen, Aviation Under the Common Law, 48 HaRv. L. Rev. 216 (1934); RHYNe, Avtation Accment LaW (1943).

${ }^{80}$ See Smith v. Pennsylvania Central Airlines Corp., 76 F. Supp. 940 (D. C., 1948). For other authorities for and against the application of the doctrine see Note, $16 \mathrm{U}$. of CEx. L. REv. 365, 367 (1949); Goldin, The Doctrine of Res Ipsa Loquitur in Aviation Law, 18 So. Cax. L. REv. 15, 124 (1944); O'Connor, Res Ipsa in the Air, 22 IND. L. J. 221 (1947); McLarty, Res Ipsa Loquitur Doctrine in Airline Passenger Litigation, 37 VA. $L$. Rev. 55 (1951); Note, 28 N. C. L. Rev. 432 (1950).

81 See, e.g., Rochester Gas \& Elec. Corp. v. Dunlop, 148 Misc. 849, 852, 266 N. X. Supp. 469, 473 (1933): "Such chance as there may be that a properly equipped and well handled aeroplane niay still crash ... sball be borne by him who takes the machine aloft."

82 C. III, Art. 22, 49 Stat. 3019 (1935). Cf. Rhyne, International Law and Air Transportation, 47 MICH. L. REv. 41 (1948).

83 See Uniform Aeronautics Act, 11 U. L. A. 173 (1938); Note, 16 U. of CHr. L. REv. 365, 371 (1949); Coblentz, Limitation of Liability for Aircraft, 23 So. Cax. L. Rev. 473 (1950).

${ }^{84}$ See Harvin, Liability of Electric Company for Personal Injuries, [1947] Irs. L. J. 794 (1947); Challener, Injuries Incident to the Production and Use of Electricity in Pennsylvania, 24 TEArPLE L. Q. 42 (1950).

${ }^{85}$ See Tipton, Liability of a Gas Company for Personal Injatries, [1948] INs. I. J. 275 (1948).

${ }^{86}$ See, e.g., Wells v. Palm Beach Kennel Club, 35 So. (2d) 720 (Fla. 1948) (patron at dog race track slipping on grandstand; Rafter v. Dubrock's Riding Academy, 75 C. A. (2d) 621, 171 P. (2d) 459 (1946); Salevan v. Wilmington Park, 72 A. (2d) 239 (Del. Super. 1950) (pedestrian hit by baseball from adjoining ball park); Prosser, TORTs \& 79; Note, 47 Micr. L. Rev. 588 (1949).

87 See Steinfeld, The Hotel-Always the Insurer, [1947] Iss. L. J. 316 (1947). See also Maryland v. Manor Real Estate \& Trust Co, et al, 176 F. (2d) 414 (4th Cir. 1949) ("Negligence" liability of U.S. Governnient as lessor of apartment house); and for a warehouse liability case George v. Bekins Van \& Storage Co., 33 Cal, (2d) 834, 205 P. (2d) 1037 (1949). 
[§ 6.] (b.) Immune entrepreneurs (governmental subdivisions, charities, and trusts). The ancient maxim that "the King can do no wrong" has long proved inappropriate where the "King" has come to compete with private enterprise and where enterprise liability is not related to a "wrong" done. But, after initial attenipts at abolishing the immunity rule, ${ }^{88}$ fear of exposing governmental enterprise to intolerable burdens at the taxpayer's expense has enabled that rule to withstand the general advance of corporate hability. Thus, for a long time, governmental liability was himited to "proprietary" activities and to what purported to be a strict liability for nuisance. ${ }^{89}$ More recently, lowever, dissatisfaction with artificial distinctions and the enormous growth of governmental activities has caused the extension of governmental liability by sucl statutory enactments as the Federal Tort Claims Act, ${ }^{90}$ by voluntary recognition of a "moral obligation"91 and by the spread and recognition of "liability" insurance for immune activities. ${ }^{92}$ But neither the old immunity rule nor its abolition can take account of the fact that losses caused by governmental enterprise may require distribution either among its beneficiaries or among taxpayers, or of the fact that the doctrine of respondeat superior as the enterprise hability vehicle of the law of negligence, is wholly inadequate if applied to public employee "wrongdoers" in what should be a domain of public law. ${ }^{93}$ These and other considerations have

88 See, e.g., Hooe v. Alesandria, 1 Cr. C. C. 98, 12 Fed. Cas. No. 6667 (U.S.C.C.) (1802).

89 See, e.g., Bingham v. Board of Education of Ogden City, 118 Utah 582, 592, 223 P. (2d) 432, 438 (1950); cases collected in 156 A.L.R. 692, 714 (1945); Barnett, The Foundation of the Distinction between Public and Private Functions in Respect to the Common-Law Tort Liability of Municipal Corporations, 16 ORE, I. REv. 250 (1937). The theory of nuisance carried municipal tort liability for a considerable period. See Warp, The Law and Administration of Municipal Tort Liability, 28 VA. L. REv, 360, 367 (1942); Peterson, Governmental Responsibility for Torts in Minnesota, 26 MINN. L. REv, 293, 480, 613, 700, 854 (1942); Fuller-Casner, Municipal Tort Liability in Operation, 54 HaRv. I. REv. 437 (1941). More recently the law of nuisance seems to have lost its independent significance. See Prosser, Torts 553; Winfield, Nuisance as a Tort, 4 CancB. I. J. 189 (1930); Potter, Princtiples of Liability In Tort 37 (1948).

9060 Stat. 842, 28 U.S.C.A. \$ 921. See Comment, The Courts and the Federal Tort Claims Act, 98 PA. L. Rev. 884 (1950). For a typical state statute see the New York Court of Claims Act, Laws 1939, p. 2178,2181 c. $860, \S 8$.

91 See Note, 33 MTNN. L. REv. 634, 637 n.13 (1949).

92 See, e.g., 1 Minn. Stat. $\$ 125.0656$ (1945) (authorization of school districts to insure); Rogers v. Butler, 170 Tenn. 125, 92 S.W. (2d) 414 (1936) (waiver of immunity by insurance); La Mourea v. Rhude, 209 Minn. 53, 295 N.W. 304 (1940) (recovery against insurer of immune tortfeasor under third party beneficiary contract theory); infra note 98. Cf. James and Thornton, supra note 9, at 438.

03 See the writer's Soldiers' Liability for Wrongs Committed on Duty, 30 CoRs. I. Q. 179 (1944); Fatracan, The Law of Martial Rule 313 (1943); and in general David, The Torr Lrabinty of Public Officers (1940). On a possible criminal hability of the Crown, see Friedmann, Public Welfare Offences, Statutory Duties, and the Legal Status of the Crown, 13 MOD. L. REv. 24 (1950). 
prompted the demand for a statutory compensation scheme. ${ }^{04}$ Here too, however, I believe, that a new analysis of the law of enterprise "negligence" could bring relief without legislative interference.

Tort liability of charities is, in the words of Mr. Justice Rutledge, characterized by "paradoxes of principle, fictional assumptions of fact and consequence, and confused results." The common law rule of immunity can no longer be supported by a traditional rationale ${ }^{06}$ and has "become merely a relic in the multitude of departures." Though most jurisdictions nevertheless adhere to that rule, the availability of liability insurance, having virtually removed the need for the protection of the "trust fund" against tort claims, ${ }^{98}$ may ultimately result in the abandonment of the immunity of charitable enterprise, if and when the resulting liability for enterprise negligence has found a new rationale. The same expectation may be justified regarding the intrafamily immunity which still purports to preserve the "amity of domestic relations" where ultimate liability rests on the insurer rather than on the father or spouse. ${ }^{100}$

${ }^{04}$ See Lloyd, Municipal Tort Liability in New York-A Legislative Challenge, 23 N. Y. U. L. Q. Rev. 278 (1948); Lloyd, Le Roi est Mort; Vive le Roi, 24 N. Y. U. L. Q. Rev. 38 (1949); and in general Symposium, Governmental Tort Liability, 9 LAW \& Contearp. Pros. 179 (1942); Green, Municipal Liability for Torts, 38 Ir工. L. REv. 355 (1944); Borchard, Tort Claims against Government: Municipal, State and Federal Liability, 33 A. B. A. J. 221 (1947). An important new phase of the problem is discussed in Knauth, Government Liability for Aircraft Damage, 37 Inc. L. REv. 355 (1944); Borchard, Tort Claims against Government: Municipal, State and Federal Liability, 33 A. B. A. J. 221 (1947).

95 President and Directors of Georgetown College v. Hughes, 130 F. (2d) 810, 812 (D. C. 1942).

06 See, e.g., Powers v. Mass. Homeopathic Hosp., 109 Fed. 294 (C.C.A. 1st, 1901) (waiver by beneficiary); Southern Methodist Hosp. (\& San. v. Wilson, 45 Ariz. 507, 46 P. (2d) 118 (1935) (inapplicability of respondeat superior); Lindler v. Columbia Hosp., 98 S. C. 25,81 S. E. 512 (1914) (public policy); infra note 98 ("trust fund" doctrine). For a good compilation see Comment, 2 VAND. L. REv. 660 (1949).

97 President and Directors of Georgetown College v. Hughes, supra note 95, at 817.

98 See Wendt v. Servite Fathers, 332 III. App. 618, 76 N. E. (2d) 342 (1947); Note, 43 IIf. L. REv. 248 (1947); [1948] INs. L. J. 120 (1948). See also O'Connor v. Boulder Ass'n, 105 Colo. 259, 96 P. (2d) 835 (1939); Vanderbilt University v. Henderson, 23 Tenn. App. 135, 127 S.W. (2d) 284 (1938) [cited with approval Baptist Memorial Hosp. v. Couillens, 176 Tenn. 300, 140 S.W. (2d) 1088 (1940), and Anderson v. Armstrong, 180 Tenn. 56, 171 S.W. (2d) 401 (1943); Andrews v. Y.M.C.A., 228 Iowa 374, 410, 284 N.W. 187, 205 (1939), quoted with approval Foster v. Roman Catholic Diocese of Vermont, 116 Vt. 76, 70 A. (2d) 230 (1950); Moore v. Moyle, 405 Ill. 555, 92 N.E. (2d) 81 (1950). A similar problem has arisen with regard to governmental liabilities. See Pohland v. Sheboygan, 251 Wis. 20, 27 N.W. (2d) 736 (1947). The "trust fund" doctrine seems to have originated in a dictum of Lord Cottenham in Feoffees of Heriot's Hosp. v. Ross, 12 C. \& F. 507, 513, 8 Eng. Rep. 1508, 1510 (1846).

99 Shumaker, Action for Tort between Husband and Wife, 30 LAW Nores 165 (1926). See also Haglund, Tort Actions between Husband and Wrife, 27 GEo. L. J. 697, 893 (1939); James and Thornton, supra note 9, at 434; and infra note 154.

100 See, e.g., Dunlap v. Dunlap, 84 N. H. 352, 150 Atl. 905 (1930). See also dissents 
Trusts and corporations, like charitable institutions, have often been used to protect entrepreneurs from an unlimited hability likely to impair daring and initiative. But the immunity of slareholder and estate will hardly survive the impact of liability insurance any longer than the immunity of governmental and charitable enterprise. While pertinent developments in the law of corporations probably do not yet permit conclusive discussion, ${ }^{101}$ the immunity of entrepreneur trust estates seems decisively affected by recoveries against them of trustees and even of third parties, under tests whicl, I believe, support the classification of negligence liabilities here suggested. ${ }^{102}$

[§ 7.] (c.) Products liability. The development of tort law from rudimentary strict liabilities and a general liability for negligence towards compensation and loss distribution can perhaps be best observed in the changing pattern of the products liability of manufacturers and other sellers. ${ }^{103}$ As to food sales, considerations of public health led to the early adoption of strict liabilities based on penal statutes or implied warranties of wholesomeness. ${ }^{104}$ But as to other sales there prevailed until the nineteenth century "the legal presumption of the buyer's ability to look out for himself," generally formulated in the maxim of caveat emptor. ${ }^{105}$ Limitation of the buyer's relief to the breach of express warranties was deemed "best calculated to excite the caution and attention

in McKinney v. McKinney, 59 Wyo. 204, 247, 135 P. (2d) 940, 956 (1943) and Cowgill v. Boock, 189 Ore. 282, 309, 218 P. (2d) 445, 458 (1950). The statutory abolition of "no action" clauses in insurance contracts (excluding the insurer's liability for noncollectible claims against an insolvent insured) is another expression of this trend. See James and Thornton, supra note 9 , at 436 .

101 Inroads in that immunity are theories such as those of ultra vires, abuse of voting power or dangerons corporate activity.

102 See Umiform Trusts Act, Sec. 14, 9 U. I. A. 719, adopted in five states; and in general, Fulda and Pond, Tort Liability of Trust Estates, 41 CoL. I. REv. 1332 (1941); infra \& 21 .

103 See Prosser, Torts 666 et seq.; Products Liability, supra note 1, and the writer's Note, 8 U. of CEI. I. REv. 162 (1940). The term "products liability," though generally used in the hterature of insurance business [see Wiggers, Producrs IIAamitx Insurance

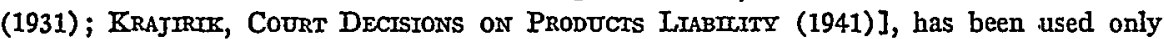
hesitatingly in legal hterature. But see, e.g., Lewis, Theories of Action in Products Liability Litigation, [1947] INs. L. J. 30 (1947); Robb, A Storekeeper's Liability, [1948] INs. L. J. 489, 491 (1948):

104 See Morris, The Relation of Criminal Statutes to Tort Liability, 46 HaRv. L. Rev. 453 (1933); Thaler, Liability for Sale of Impure Foods, 11 BrookLYN L. Rev. 209 (1942); Products Liability, supra note $1, \S \S 3$ ff. The theory of imphed warranty, based upon a passage in Blackstone [3 CommentarIes 165 (ed. Lewis, 1900)] and appearing in New York as early as 1815 [Van Bracklin v. Fonda, 12 Johns. 468] and 1837 [dissent in Wright v. Hart, 18 Wend. 449, 455] has become the law in inost jurisdictions. See Prosser, The Implied Warranty of Merchantable Quality, 27 Mrnv, I. REv. 117, 118, 132 (1943).

105 Hamilton, The Ancient Maxim Caveat Emptor, 40 Y ALE L. J. 1133, 1135 (1931). See also Metick, The Sale of Food and Drink (1936). 
which all prudent men ought to observe in making their contracts."100 Even the Uniform Sales Act, adopted in most jurisdictions, while extensively relying on implied warranties, ${ }^{107}$ limited protection by various requirements such as declaration of purpose, rehance, and privity. Judicial attempts at escaping these limitations by presumptions and statutory construction ${ }^{108}$ have been only partly successful and have rarely been supported by legislation. ${ }^{109}$ Though the need has been for compensation of the victim of the inevitable incidents of modern enterprise, the victim's protection lias-here as elsewhere-largely developed within a rule of liability for fault. ${ }^{110}$

From Winterbottom $v$. WTright ${ }^{111}$ with its argument in terrorem against third party recovery, through Thomas $v$. Winchester"12 with its "inherent danger" formula, a wellknown chain of judicial law making has led to MacPherson v. Buick Motor Co. ${ }^{113}$ with its general negligence liability for articles "dangerous if negligently made." This rule has been adopted and developed in most jurisdictions and included in Section 395 of the Restatement of Torts. However, if inducement of producers to prevent "negligence" in their enterprises has ever been a ground for this rule, it has lost its meaning at a time when, with the spread of hability insurance,

106 Seixas v. Woods, 2 Caines 48, 54 (N. Y. 1804). See also 2 Kent, Comamentarues on AMIERICAN LAW 478, 490, 491 (4th ed., 1840).

1071 U. L. A. 103, \& 15. See Comment, Should the Doctrine of Implied Warranties be Limited to Sales Transactions?, 2 VAND. L. REv. 675 (1949).

108 See Rinaldi v. The Mohican Co., 225 N. Y. 70, 121 N. E. 471 (1918) (presumption of declaration of purpose and reliance); Leidy, Another New Tort?, 38 MrCH. L. REv. 964, 983 (1940); Products Liability, supra note 1, \& 7; Klein v. Duchess Sandwich Co., 14 Cal. (2d) $272,283,93$ P. (2d) 799, 804 (1939) ("clear intent of the legislature"). See also the excellent discussion of these and other "fictions" by Justice Traynor in Escola v. CocaCola Bottling Co., 24 Cal. (2d) 453, 465, 150 P. (2d) 436, 442 (1944).

109 See Conn. (1939) Supplement to Gen. Stat. c. 232 (Pub. Acts $§ 186) \S 1276$ (e), overruling Borucki v. MacKenzie Bros. Co., 125 Conn. 92, 3 A. (2d) 224 (1938) and extending the consumer's protection to "all members of the buyer's lousehold." Similar proposals in New York [e.g., (1943) Sen. Int. No. 224, Pr. No. 226, Assembly Int. No. 216, Pr. No. 218] bave apparently hittle chance of overcoming the ill-considered resistance of insurers. Section 2-318 of the Uniform Commercial Code (Spring, 1950, Draft) would extend all express and imphied warranties "to any natural person who is in the family or household of the buyer or who is his guest or one whose relationship to him is such as to make it reasonable to expect that such person may use, consume or be affected by the goods."

110 See, e.g., Llewellyn, On Warranty of Quality and Society, 36 Cor. L. Rev. 699 (1936) ; Winfield, The History of Negligence in the Law of Torts, 42 L. Q. REv. 184 (1926); Seefeld, Tort Liability of Manufacturers to Users of Their Goods, 25 Marq. L. REv. 173 (1941); Morrow, Warranty of Quality: A Comparative Sturvey, 14 TULANe L. Rev. 327, 529 (1940).

11110 M. \& W. 109, 11 L. J. Ex. 415, 152 Eng. Rep. 402 (1842).

1126 N. Y. 397, 57 Am. Dec. 455 (1852).

113217 N. Y. 382, 11 N. E. 1050 (1916). For an illuminating analysis of this development see Levi, An Introduction to Legal Reasoning, 15 U. of CHI. L. REv. 501, 572 (1948). 
the sanction of the rule has, in general, dwindled to a mere threat of increased insurance premiums. ${ }^{114}$ Moreover, once loss distribution through the insurer is recognized as an essential function of the products hability of the McPherson rule, that liability should no longer be withheld from large groups of articles and interests. ${ }^{115}$

[§ 8.] (d.) Other liabilities. Ever since the House of Lords held a newspaper liable for damage innocently done to the reputation of Artemus Jones by a presumably fictitious story ${ }_{116}^{116}$ strict liability has been imposed for the publication in print or in writing of a defamatory statement. This rule has been much criticized as impairing freedom of speech, promoting strike suits, and unnecessarily placing words "in the same class with the use of explosives or the keeping of dangerous animals."117 In view of similar criticism as to radio broadcasts, return to the negligence rule, otherwise applicable only to mere "disseminators," has been advocated and occasionally adopted, at least with regard to "ad libs" as distinguished from prepared texts. Thus, in Kelly v. Hoffman a public official accused in a radio broadcast of malfeasance, was denied recovery against the broadcasting company which had leased its facilities to the broadcaster's employer, because the defendant "could not have prevented publication by the exercise of reasonable care."118 Under this theory a broadcasting company would, in effect, be hable only where it has "failed to exercise reasonable care to see to it that no scandalmonger should take advantage of its facilities."119 It is submitted that analogous application of the "negligence" tests developed for other dangerous enterprise activities may produce a more effective protection of the public, without imposing an excessive strict liability. Here, too, the availability of liability insurance should greatly influence the tort rule. ${ }^{120}$

114 See Sawyer, Compensation Rates and Safety, 42 BesT's No. 2, 47 (1941); and in general the brilliant discussion of the "impact of liability insurance" on tort law by James, supra note 9, 557 et seq.

115 For an analysis of the law of New York in this respect see the writer's Products Liability, supra note 1. For a recent extension of the rule see Foley v. Pittsburgh-Des Moines Co, 363 Pa. 1, 68 A. (2d) 517 (1949) (realty). Cf. La Rocca v. Farrington, 301 N. Y. 247, 93 N. E. (2d) 829 (1950).

116 Fulton \& Co. v. Jones, [1909] 2 K. B. 444, af'd [1910] A. C. 20.

117 Prosser, TORTs 817. See also Donnelly, The Law of Defamation: Proposals for Reform, 33 MINv. L. REv. 609, 613 (1949); Note, Television and Torts, 15 Mo. L. REv. 48 (1950); Note, Libel and Slander; Defamation by Television, 3 OKLA. L. REv. 446 (1950). 118137 N. J. L. 695, 702, 61 A. (2d) 143, 147 (1948). See also REst. ToRTs, SEc. 581, comment $f$ (1938); Summit Hotel Co. v. National Broadcasting Co., $336 \mathrm{~Pa} .182,8 \mathrm{~A}$. (2d) 302 (1939); Josephson v. Knickerbocker Broadcasting Co., 179 Misc. 787, 38 N. Y. S. (2d) 985 (Sup. Ct. 1942).

110 Kelly v. Hoffman, supra note 118 at 702, $61 \mathrm{~A}$. (2d) at 147, quoting with approval from Bohlen, Fifty Years of Torts, 50 HaRv. L. REv. 725, 731 (1937).

120 Such insurance has been written since 1930 by the Employers Reinsurance Cor- 
That the need for a new type of enterprise liability for "negligence without fault" is not limited to the problems discussed, may be illustrated by two additional examples from diverse fields of tort law. Modern business requires ever increasing reliance on expert certifications such as those of public accountants, notaries, title abstractors, food inspectors, and various public officers. Fear of overextending the certifier's liability has probably prompted the courts to adhere to the doctrine of the Ultramares case ${ }^{121}$ in which negligence liability was denied as to a plaintiff whose reliance the defendant had not contemplated. Though sucli plaintiffs might be protected where the defendant's neghigence is serious enough to amount to "deceit," recovery is now denied against business enterprises inviting general reliance. Perhaps a new type of negligence liability "without fault," based on insurability, could fill the gap now only partly and unsatisfactorily covered by actions in warranty and deceit. ${ }^{123}$

As a final illustration for the virtually unlimited scope of the problem, reference may be made to the decision in Summers $v$. Tice, ${ }^{124}$ holding jointly liable in negligence two members of a hunting party one of whom had negligently shot the plaintiff. This decision has been criticized for relying on a shift of the burden to prove causation. ${ }^{125}$ But perhaps this shift does not go far enough in that the plaintiff is still required to prove the defendants' negligent conduct beyond the creation by them of risks inherent in their common hazardous activity. ${ }^{128}$ Abandonment of this requirement and recognition in such cases of an enterprise liability for harm typically and insurably caused may be foreshadowed in a decision referred to in the Summers case in which the same court held that, under the doctrine of res ipsa, ${ }_{127}^{127}$ "where a plaintiff receives unusual injuries

poration of Kansas City, Missouri. See Donnelly, Defamation by Radio: A Reconsideration, 34 IowA L. REv. 12, 21 n.43 (1948) with further references.

121 Ultramares Corporation v. Touche, 255 N. Y. 170, 174 N. E. 441 (1931). See in general Note, Cases on Accountants Liability in New York, 1 Intramural L. Rev. OF N. Y. U. 57 (1945); Harper and McNeely, A Synthesis of the Law of Misrepresentation, 22 MnNN. L. Rev. 939 (1938); Bannister and Weller, Liability of Accountants for Negligent Failure to Discover Shortages, 18 Ins. Counser J. 28 (1951); Note, The Accotntant's Liability-For What and to Whom, 36 IowA L. REv. 319 (1951).

122 See Ultramares Corporation v. Touche, supra note 121; Stein v. Treger, 182 F. (2d) 696 (D.C. Cir. 1950).

123 See Editorial, 10 Cerrtried Public Accountant 228, 229 (1930), cited Note, 31 Cor. L. Rev. 858, 869, n.75 (1931); Prosser, Torts 743; Rest., Torts Sec. 552, comments (g), (h) (1938).

12433 Cal. (2d) 80, 199 P. (2d) 1 (1948).

125 See Comments, 37 Geo. L. J. 627 (1949); 2 VAND. L. Rev. 495 (1949). But see Notes, 47 Mich. L. Rev. 1232 (1949); 27 TEX. L. REv. 732 (1949).

${ }^{126}$ See Prosser, supra note 3, at 389; Prosser, Joint Torts and Several Liability, 25 Catif. L. Rev. 413, 420, 432 et seq. (1937).

127 See supra, \& 4. 
while unconscious and in the course of medical treatment, all those defendants who had any control over his body or the instrumentalities which might have caused the injuries may properly be called upon to meet the inference of negligence by giving an explanation of their conduct."128 These and other cases discussed in the preceding sections will be reëxamined below in the hight of the theory of hability for negligence without fault here proposed as the "true rule" of the neghigence hability of dangerous enterprise.

\section{B. The Crisis of the Rule}

\section{[§ 9.] 1. "Negligence" Restated}

This study has undertaken to ascertain and analyze those types of enterprise hability which, while developed as habilities for negligence, resemble habihities without fault in extending, on the one hand, to hatm caused by nonreprehensible conduct and, on the other hand, to harm not foreseeable by the person causing it. For the purposes of this investigation, it seems desirable to restate, disregarding many exceptions and modifications, the essential elements and functions of what is now indiscriminately referred to as liability for negligence.

Section 282 of the Restatement of Torts defines negligence as conduct "which falls below the standard established by law for the protection of others against unreasonably great risk of harm." Such conduct is seen as based either on a reprehensible state of $\operatorname{mind}^{129}$ or on the absence of "due care"130 measured by certain external standards. At the first glance these definitions would seein to permit an "absolute" characterization of conduct as negligent without regard to its consequences. Since, however, proof of damage is an essential requirement of any action in negligence, ${ }^{131}$ and

128 Ybarra v. Spangard, 25 Cal. (2d) 486, 494, 154 P. (2d) 687, 691 (1944). See also Cavero v. Franklin General Hospital, 36 Cal. (2d) 301, 223 P. (2d) 471 (1950); Prosser, Res Ipsa Loquitur in California, supra note 59 at 223.

1291 AUSTIN, Lectures on JURISprUdence (3d ed., 1869) 438; Hoctand, The EleMENTS OF JURISPRUDENCE (4th ed., 1888) 94; SALMOOND, TORTS (8th ed., 1936) 34; BIGELOW, ToRTs (8th ed., 1907) 67 et seq. For an analysis of this theory see Edgerton, Negligence, Intadvertence, and Indifference: The Relation of Mental States to Negligence, 39 HARv. L. REv. 849, 850, 867 (1926).

130 See Terry, Negligence, 29 Harv. L. Rev. 40 (1915); Buckland, The Duty to Take Care, 51 L. Q. Rev. 637 (1935); Green, The Palsgraf Case, 30 Coc. L. Rev. 789, 791 (1930); STREET, op. cit. sutpra note 12, 93 ff.; Edgerton, supra note 129, 852; Brereton, The Duty of Care, 14 Aust. L. J. 242 (1940); Carpenter, Proximate Cause, 14 So. CaLIF. I. Rev. 1, 115, 416; 15 So. Caltr. L. Rev. 187, 304, 427; 16 So. CaLIF. L. Rev. 1, 61 (1940-1943); Winfield, Duty in Tortious Negligence, 34 Cor. L. REv. 41 (1934); Marceau, supra note 42, 501 n.10. The concept seems to go back to 2 BRacton, DE LEgibus Angziae (Twiss ed., 1879) c. IV sec. 2, pp. 277, 278, and was reintroduced by HAIE, PLEAS OF THE Crown (1778) 472. See Moreland, supra note 16, 2 n.14, 5. Cf. Lawson, The Duty of Care in Negligence: A Comparative Study, 22 TUL. L. REv. 111 (1947).

131 PROSSER, TORIS 177. 
since the conduct concept itself is necessarily relational in several respects, ${ }^{132}$ an examination of the law of negligence liability can, $I$ believe, forego a concept of negligent conduct and limit itself to one of negligent causation.

Liability for negligent causation would have to be based on a subjective conception of personal fault if the admonition of the tortfeasor were the prevailing purpose of that liability. However, the law's desire to compensate the victim without regard to personal fault has caused the courts to adopt the objective standard of the reasonable man. ${ }^{133}$ Deepseated psychological reasons, yet unexplored, probably account for the fact that the law has chosen this "tour de force,"184 phrasing a prevailingly compensatory liability in language implying blame of a "wrongdoer's" conduct ("you should have acted as a reasonable man") rather than as an expression of the compensatory rationale of risk distribution. How the reasonable man would lave acted depends on whether or not he would have foreseen that harm would ensue from lis action. ${ }^{136}$ The injunction "you slall pay for harm you expected to result from your conduct" lost much of its character as a censure when it was changed into "you shall pay for harm a reasonable man would have expected to result from your

132 My "voluntary muscular contraction" (HoLMes, op. cit. supra note 13, 91) in walking in the street outside the limits of the pedestrians' zone is identifiable as "conduct" in various relations: as exercise in the open air (as, e.g., golf), as loafing during office hours (as, e.g., horseplay), or as unlawful use of the street. The necessity of this relation becomes particularly obvious in the case of tortious omissions. Out of the boundless hiterature on this subject see, e.g., Edgerton, supra note 129, 852; Terry, supra note 130, passim; Wilson, Some Thoughts about Negligence, 2 OKCA. L. REv. 275, 281 (1949).

138 This standard is "external." The Germamic, 196 U. S. 589, 25 Sup. Ct. 317 (1905). See Edgerton, supra note 129, 849; Prosser, TORTS 224. Conceptually, the distinction between "subjective" and "objective" standards of negligence is merely one of degree. All negligent (as opposed to intentional) causation, is causation "by mistake" as judged from the standpoint of an "objective" (fictitious) observer. For a general analysis see the present writer's MISTAKE AND UNLAWFULNESS (IRRTUM UND RECHTSWIDRIGKETT) (1931). But of. Whittier, Mistake in the Law of Torts, 15 HARv. L. REv. 335 (1902).

184 RoBinson, LAW AND THE LAWYER 86 (1935). Perhaps, even strict liability was originally understood as a liability for intention, conscious or subconscious. See STREET, op. cit. supra note 12 , and supra $\$ 2$.

135 "The whole idea of risk . . . is comprehended in the notion of foresight ..." Harper, The Foreseeability Factor in the Law of Torts, 7 NOTRE DAMIE LAWYER 468 (1932). For a short bibliography and a discussion of the problem along the lines of the present investigation, see Gregory, Proximate Cause in Negligence-A Retreat from "Rationalization," 6 U. of C世r. L. REv. 36 (1938). See also Loss-Shifting, supra note 1, 729 et seq.; Morris, On the Teaching of Legal Cause, 39 CGL. L. Rev. 1087 (1939); Updegraff, A Technique for Determining Legal Liability Based on Negligence, 27 IowA L. REv. 2 (1941); Malone, Theories of Causation in the Law of Negligence, 11 Kans. B. J. 353 (1943); Note, Impact of the Risk Theory on the Law of Negligence, 63 Harv. I. REv. 671 (1950); James, The Qualities of the Reasonable Man in Negligence Cases, 16 Mo. L. REv. 1 (1951); James, Proof of the Breach in Negligence Cases (Including Res Ipsa Loquitur), 37 VA. L. REv. 179 (1951). 
conduct." But it has lost that character almost entirely since it has come to read "you shall pay for harm caused by conduct which a reasonable man would have expected to cause some harm."

Foreseeability of harm by the reasonable man does not render the actor liable if he was unable to avoid the causative conduct, ${ }^{137}$ or if his conduct was lawful or "excused" because he could not be "reasonably" expected to avoid it, or in other words because the risk was justifiably incurred rather than "unreasonably." Als8 All or some of these elements are often stated in terms of "duty of care" or "proximate causation." That those tests add nothing to the above analysis has too often been proved to require further discussion. ${ }^{139}$

For the purpose of this investigation negligent causation may thus be assumed where a reasonable man in the actor's place could have foreseen a harm of the type caused and (because his conduct was neither unavoidable nor justified, that is, not in violation of "due care") could have been reasonably expected to avoid such causation.

\section{The "Siamese-Twin Functions" of Enterprise Liability for Negligence}

[§ 10.] (a.) Tort law. Though by its terms implying blame for "neglectful" conduct, the negligence rule has come to be used largely to impose liability for harm caused by the lawful activities of modern enterprise. However, the original admonitory meaming and rationale of this rule, though almost forgotten, have been preserved in the language and in occasional applications of the law. The resulting conflict between the "Siamese-twin functions" of tort law, while no doubt the basis of many

186 See Wharton, a Treatise on the Law of Negligence 12 (1st ed., 1874). Cardozo's doctrine of the "unforeseeable plaintiff" (Prosser, TORTS 182), as well as its modification in the "unforeseeable class" theory [Sinram v. Pennsylvania R. Co., 61 F. (2d) 767 (C.C.A. 2d, 1932), REsT., TORTs $\S 281$ (b), Comment (1934)] attempt to strike a middle line between a "some harm" and a "this harm" theory. For criticism see Loss-Shifting, supra note 1, 731 and Judge Learned Hand in The Glendola, 47 F. (2d) 206, 207 (C.C.A. 2d, 1931).

187 ". . . the defendant must have had at least a fair chance of avoiding the infliction of harm before he becomes answerable for such a consequence of his conduct." Horiares; op. cit. supra note $13,163$.

138 Restatearent, Torts \$ 282 (1934). The cases are well classified by Terry, supra note 130, at 42 , according to certain relations between the "magnitude," "utility," and "necessity" of the risks involved or to the respective values of the "collateral" and "principal" objects of protection.

189 See the concurring opinion by Justice Traynor in Mosley v. Arden Farms Co., 26 Cal. (2d) $213,220,222,157$ P. (2d) 372,376 (1945), commenting on the reasonable expectation "that in time the courts will dispel the mists that have settled on the doctrine of proximate cause in the field of negligence." And see Barcantine, Problears In LAw 1248 (3d ed. 1949) on the jury instructions on proximate causation which "are usually as blind, irrational and unintelligible as incantations of an Indian medicine man in driving out the evil spirits, and less useful." For an exhaustive analysis of the problem and a selective bibliography see Prosser, supra note 3, at 369. 
a sound compromise, has produced a certain "mutual hampering effect" on both functions. ${ }^{140}$

Admonitory considerations would seem to underlie the employerentrepreneur's defenses of the unforeseeability of the harm caused, of an intervening act of an independent contractor, and of plaintiff's contributory neghigence. ${ }^{141}$ Similar considerations would seem to explain why the employer-entrepreneur can be held liable for punitive damages, ${ }^{142}$ why lie is denied recourse against other tortfeasors" (the (the does not lelp the wrongdoer"), and why, notwithstanding the intervention of an independent contractor, he may be held for the violation of a "nondelegable" duty. 144

On the other hand, it should be admitted "in all honesty ... that there are now large areas of employer responsibility [to third persons], which cannot be accounted for realistically" upon a rationalization based on either the employer's or the employee's fault. ${ }^{145}$ The employer's failure carefully to select and control his employee, thougln perhaps the original basis of his hability, ${ }^{146}$ cannot be relied on, since neither careful

140 Morris, Rough Justice and Some Utopian Ideas, 24 IrL. L. REv. 730, 733 (1930). See also ibid: "The attempt is to compensate the plaintifi for one set of reasons, and to punish the defendant for an entirely different set of reasons, by the single act of making the defendant pay a sum of money to the plaintiff."

141 See, e.g., Cooley, Problems in Contributory Negligence, 89 U. OF PA. L. REv. 335 (1941) ; Patton, Contributory Negligence-Report of the Law Revision Committee, 14 Aust. L. J. 379 (1941); James, supra note 12, 395. This entire phase of the problem including "comparative negligence," "Iast clear chance," and "assumption of risk," will be discussed separately.

142 See, e.g., Goddard v. Grand Trunk R.R. of Canada, 57 Me. 202 (1862) ; New Orleans, etc. R.R. v. Bailey, 40 Miss. 395 (1866); Holmes, Agency, 4 HARv. L. Rev. 345 (1891). For a fine Comment on the "Insucrer's Liability for Punitive Damages," see 14 Mo. L. REv. 175 (1949).

143 See Gregort, Legislative Loss Distribution in Negligence Actions (1936); Gregory, Contribution Among Joint Tortfeasors: A Defense, 54 HARv. L. REv. 1170 (1941); Bohlen, Contribution and Indemnity between Tortfeasors, 21 CoRN. L. Q. 552 (1936); Leflar, Contribution and Indemnity between Tortfeasors, 81 U. OF PA. L. REv. 130 (1932); James, Contribution Among Joint Tortfeasors: A Pragmatic Criticism, 54 Harv. L. REv. 1156 (1941); Kinnally, Contribution or Indemnity Among Joint Tortfeasors, 18 NoTRE DATOE LAwXER 36 (1942); Notes, Legislative Efforts to Distribute Loss Between Joint Tortfeasors, 45 HARv. L. REv. 369 (1931); Indemnity and Contribution Between Joint Tortfeasors, 34 YaLe L. J. 427 (1925) ; 21 MivN. L. Rev. 764 (1937). See also N. Y. State Leg. Doc. (1941) No. 65 (A), Report of the Law Revision Commission (1941) 29 et seq., with references to earlier studies; and Meriam and Thornton, Indemnity between Tort-Feasors: An Evolving Doctrine in the New York Court of Appeals, 25 N.Y.U.L. REv. 845, 858 (1950). 144 See, e.g., Notes, 49 W. VA. L. Q. 59 (1942); 87 U. OF PA. L. REV. 728; authorities collected in Steffen, Cases on the Law of Agency, 247 et seq. (1933).

145 Steffen, Independent Contractor and the Good Life, supra note 58, at 507.

146 See, e.g., Sleath v. Wilson, 9 Car. \& P. 607, 611, 173 Eng. Rep. 976, 978 (1839): "This is for the purpose of inducing those who employ others that they employ proper persons"; Goddard v. Grand Trunk Ry. of Canada, supra note 142. See also Seavey, supra note 24,447 . This theory "need not be taken seriously." Radin, supra note 12, 707. 
selection nor careful control can be pleaded as a defense. ${ }^{147}$ And the employee's fault is hardly enough since few employees would be held personally liable on such slender evidence of "negligence" as a jury might deem sufficient to impose liability on their wealthy and presumably insured employers. Indeed, verdicts against employers have occasionally been upheld though based on the very negligence of which their employees had been acquitted. ${ }^{148}$ Whether these and other anomalies can be rationalized under a new theory of enterprise liability will be discussed below.

[§ 11.] (b.) Insurance. Notwithstanding judicial, legislative, and contractual extensions of vicarious bability ${ }^{149}$ even an admittedly compensatory law of enterprise liability could not fully secure indemnification unless supported by some scheme insuring the solvency of the party liable. Where "self-insurance" is not feasible because of the peculiarity of the risk or the size of the enterprise, liability insurance has come to supplement and correct the law of torts. The consequences of this development have been mamifold and significant. On the one hand, liability insurance has not escaped the conflict between admonitory and compensatory policies inherent in the liability insured. On the other hand, the very existence of liability insurance has greatly affected the development of that conflict.

Only in exceptional situations can an adequate distribution of risk be expected through the victim's own insurance of his property, accident, or life. The member of the public who in a single day may be a railroad passenger, an automobile guest, a consumer of food, and a hospital patient, cannot be expected to carry insurance against all risks thus incurred. Yet, where such insurance can be expected, as in the case of the house owner and his fire risk, tort law has been significantly affected by the availability of insurance. Once "negligence" is established in the setting of fire, mere pliysical remoteness of the damaged property will not limit the defendant's

147 See Y. B. Smith, supra note 24, 455, 724; Steffen, supra note 58, Douglas, Vicarious Liability and Adninistration of Risk, 38 YALE L. J. 584, 720 (1929). This is true even under a statute providing for such a plea. See Miller, The Master-Servant Concept and JudgeMade Law, 1 Loyoza L. Rev. 25, 30 (1941): Section 2320 of the Louisiana Civil Code which declares an employer to be liable only where he might have prevented the servant's act, has been construed out of the text. Legal historians and sociologists now have occasion to observe a similar development of a respondeat superior rule from a device of adinonition into one of compensation. The Suprenie Court of Austria, interpreting a statute clearly based on an admomitory rationale (Austrian Civil Code, Sec. 1315), has recently declared that strict liability analogies must be apphed in determining the enterprise master's liability for his servant. See supra note 52 .

148 See infra $\$ 19$. Even where the employee's fault demands punishment, threat of discharge and criminal prosecution will prove more effective than an uncollectible judgment. Similar considerations underlie those Continental automobile statutes which exempt the professional chauffeur from their (strict) liability rule.

149 See James, supra note 12, 564 et seq. 
liability. In the balance of equities the innocent victim's claim to compensation weighs more heavily than any injustice done to the defendant by the imposition of a burden out of proportion to his fault. ${ }^{160}$ But this proportion may be decisive where the victim could and should have secured insurance protection. Thus, in the largely metropolitan jurisdiction of New York availability and generality of such insurance has produced a unique limitation of the liability for neghigent fires to the next adjoining house. ${ }^{151}$ Similar developments lave occurred, and are likely to occur, with regard to liability insurance. ${ }^{\mathbf{1 5 2}}$

For the last fifty years that insurance, by protecting the injurerentrepreneur, has removed many obstacles against the expansion of his liability for harm inflicted by lawful activities. ${ }^{153}$ Similarly, the existence, or even availability, of liability insurance has rendered irrelevant, and occasionally overcome, the rationale of other immunities, such as those of members of the plaintiff's family (protection of the integrity of the family) $)^{154}$ or of infants (hunanitarian reasons). ${ }^{165}$ And, overtaking legal progress by great strides, insurance business has begun to protect victims of dangerous activities without regard to the injurer's liability.

Once the impact of liability insurance on liability is recognized as legitimate, evidence of the existence of such insurance must become generally admissible. ${ }^{156}$ And ultimately the victim will secure his compensation by direct suit against the insurer, now only occasionally permitted where the injurer is unascertainable, absent, or insolvent.

Insurance protection of the public against the hazards of modern enterprise, however greatly expanded judicially, legislatively, and contractually, can be complete only under some system of compulsion. In the fields of workmen's compensation ${ }^{157}$ and automobile insurance ${ }^{168}$ recogni-

150 See Prosser, TORTS 346.

151 See Ryan v. New York Cent. R.R., 35 N. Y. 210, 91 Am. Dec. 49 (1866); Note, 32 Cor. L. REv. 911 (1932).

152 Assurance Oblige, supra note 1 , at 450 with references.

153 See McNeely, The Genealogy of Liability Insurance Law, 7 U. OF PITT. L. Rev. 169 (1941); Headley, The Growth and History of Automobile Insurance in 1 Howe, ReAdrvos on Insurance (1923); Michex, Essay d'une Théorde Genterale Sur l'assurance-ResponSABIITÉ (1914).

154 See James, supra note 9, 553; McCurdy, Torls between Persons in Domestic Relations, 43 HARV. I. REv. 1030 (1930); and supra note 99.

155 See James, supra note 9, 554 with references.

156 See Note, Disclosure of Insurer's Interest in Voir Dire Examination of Jurors in Illinois, 43 In工. L. REv. 650 (1948); J. R. Wilson, Evidence of Insurance Liability in Texas, 2 BAYLoR L. REv. 25 (1949).

157 See Prosser, Torts 518 et seq.; and e.g., J. Smith, Sequel to Workmen's Compensation Acts, 27 HARv. L. REv. 344 (1914); Lenhoff, Insurance Features of Workmen's Compensation Laws, 29 CoRN. L. Q. 176, 353 (1943, 1944).

158 See, e.g., Note, Auto-Accidents-What Shall We Do About Them?, 27 MnNv. L. REv. 103 (1942); supra note 8. 
tion of this fact has produced legislative schemes which are being advocated also for other types of enterprise liability. ${ }^{169}$

This entire development is greatly hampered by the lack of a distinction between the admonitory and compensatory elements of "negligence" liability. Affecting the entire field of that liability, insurance lias come to protect the guilty with the innocent, thus defeating whatever remains of the original rationale of liability for moral negligence. This fact may partly account for the historical and still persisting doubt as to the "legality" of liability insurance in general, ${ }^{160}$ a doubt which, I beheve, would become meaningless in relation to the "true rule" of enterprise hability.

II

THE TRUE RULE: "NEGLIGENCE WITHOUT FAULT"

\section{A. The New Rationale}

[§12.] What has been shown so far is that, when the industrial revolution demanded a new rule to protect the victims of the hazards of modern mechanical enterprise, various historical, economic, and psychological reasons prompted the courts to grope for this new rule within the traditional law of negligence $(\S \S 2,3)$. It lias further been shown that this technique ignored the inapplicability to liarm of a type inevitably caused by lawful activities, of a liability for the reprelensible causation of avoidable harm ( $\S 4,9)$; that consequently, to inake the old rule serve new needs, legalistic devices had to be used, sucl as the doctrines of res ipsa loquitur (presumption of or prima facie case for reprehensible conduct) and respondeat superior (imputation of such conduct to lawful enterprise) ( $\$ 4)$; and that this development can be observed in many fields of enterprise liability (some of which have been specifically discussed, $\S \S 5-8$ ). After a restatement of the concept of negligence (§ 9) it has finally been suggested that the use of that concept which implies blame, within a scheme of liability primarily designed to secure compensation, has caused many inconsistencies ( $\S 10,11$ ).

In the following pages the attempt will be made to slow that some of these inconsistencies can perhaps be removed by a conscious analysis of what may be characterized as a law of liability for "negligence without fault," gradually and nonconsciously developed within the traditional

${ }^{169}$ See, e.g., with regard to products liability, Jeanblanc, Manufacturers Liability to Persons Other Than Their Immediate Vendees, 24 VA. L. REv. 134 (1937); with regard to railroad liability, Ballantine, A Compensation Plan for Railway Accident Claims, supra note 44.

160 See McNeely, Illegality as a Factor in Liability Insurance, 41 Cox. L. Rev. 26 (1941); Gardner, Insurance against Tort Liability-An Approach to the Cosmology of Law, I5 LAw AND Contearp. Prob. 454, 462 (1950). 
concept of fault. In a search for the rationale and scope of that liability it seems appropriate first to examine those enterprise habilities which, as "strict" liabilities, developed their language and rationale independently from the law of negligence.

\section{Strict and Quasi-Strict Enterprise Liabilities}

[§ 13.] (a.) At different times, in different countries, under the civil as well as under the common law, a "strict" or "absolute" liability ${ }^{1}$ has been connected with certain activities. " The similarity of these "strict liability" rules under the several legal systems can hardly be coincidence. This similarity slould keep us from belittling such rules in our own law as relics of a by-gone age, ${ }^{3}$ and it certainly justifies the search for a common rationale.

This search is hampered by the fact that these liabilities, even after the decline of the writ system, have never been organized under a general principle, and thus could not withstand the intrusion of the fault dogma into their language, if not their substance. ${ }^{4}$ Thus the doctrine of respondeat superior was rationalized as a liability for fault, ${ }^{5}$ even after having been divested of the meaningless fiction identifying the master with the guilty employee. ${ }^{6}$ The same is true, to a varying degree, for the liability for animals, for the rule of Rylands v. Fletcher, and for the liability for fire caused by railroad sparks. ${ }^{7}$ And even the liability for

1 The term "strict liability" now seems to be generally preferred. While J. Smith still speaks of "Tort and Absolute Liability" 30 HARv. L. REv. 241 (1917), and Winfield still finds it necessary to plead for "strict" liability as the better term [The Myth of Absolule Liability, 42 L. Q. REv. 37 (1926)], the leading textbooks by HARPER, A TREATISE ON THE LAW of Torts (1933) and Prosser, Handbook of the LAW of Torts (1941) now use "strict liability" almost exclusively.

2 See Prosser, Torts 426 ff.; HARper, op. cit. supra note 1, 331 ff.; James, Accident Liability: Some Wartime Developments, 55 YaLE L. J. 365 (1946); Takayanagi, Liability without Fault in the Modern Civil and Common Law, 16 IrL. L. REv. 163, 268; 17 Irr. L. REV. 187, 416 (1921-1923). For a survey of the Continental literature on liability without fault see BIENENFEID, LIABHITIES WITHOUT FaULT (HAFTUNGEN OHNE VerschULDEN) (1933). See also the writer's TORT LIABIITTY FOR FAULT (ScHUIDHAFTUNG IM SCBADENERSATZRECHT) 40 (1936).

${ }^{3}$ See J. Smith, Tort and Absohute Liability-Suggested Changes in Classification, 30 HARV. L. REV. 241, 319, 409 (1916-1917).

${ }^{4}$ See Part I, $\$ \$ 2$ et seq. On the change incurred by the action for trespass to land under this inpact see Winfield and Goodhart, Trespass and Negligence, 49 L. Q. REv. 358, 363 (1933); James, supra note 2, 366; and Restatearons, ToRts \& 166 (1934).

5 See Part I, \& 3.

6 Holmes, Agency, 4 Harv. L. Rev. 345 (1891); Seavey, Speculations as to "Respondeat Superior," Harvard Legar Essays 445 et seq. (1934); Radin, A Speculative Inquiry into the Nature of Torts, 21 TEx. L. REv. 697, 707 (1943). For a novel "status" theory see Miller, The Master-Servant Concept and Judge-Made Law, 1 LoyouA L. REv. 25 (1941).

7 See Holares, The Comenon Law 20, 156 (1881); 1 Street, The Foundations of Iegal Liability 51, 62 ff. (1906); Priboy, L'Idé de Fadte et IA Responsabitté des 
blasting has been said to be "actually based on fault-a very high degree of fault verging on that characterized as intentionality."8 This as well as the opposite tendency transforming the fault concept into a tool of strict liability, has obscured the rationale of the historical strict liabilities, and, to some extent, justified the statement that the question whether there is "liability with or without 'fault' must beg its own conclusion."" But it is submitted that the scope of these strict liabilities can perhaps furnish the clue to their rationale and, in further analysis, to that of the "true rule" of the related enterprise liability for "negligence."

Under an ancient rule the owner of a wild animal is "strictly" liable for harm caused by it. Does this hability extend to larm caused by a tiger who was released from its cliain by lightning? Though Lord Bramwell once thought it did, ${ }^{10}$ the law is clearly to the contrary. The owner leading along a street a docile bear is not liable for injuries caused by a horse frightened by the bear's appearance. ${ }^{11}$ Limitations concerning the manner of occurrence and the scope of protected parties, ${ }^{12}$ have in general been based on the consideration that the harm caused was not "within the extraordinary risk whose existence calls for such [strict] responsibility."13

If negligent causation is causation of foreseeable and avoidable larm, harm caused by the keeping of a wild animal is negligently caused. But, having been permitted or even encouraged by the law, the defendant's conduct lacks the reprehensibility required for the imposition of liability for negligence. In some cases strict liability is the price an entrepreneur must pay for that permission. Under the above rule that liability extends to all harm for the infliction of which he would be liable but for the permission, i.e. to that "general type of harm" the causation of which was foreseeable and aviodable when he started his hazardous activity, no

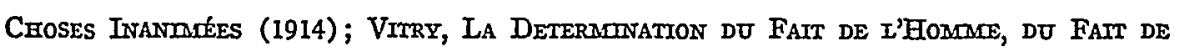
L'ANarar ET DU FAIT DE LA Chose (1932) (aninals); Harper, Liability without Fault and Proximate Cause, 30 MICr. L. Rev. 1002, 1005 (1932); J. Smith, supra note 3, at 414, n.23; Dickinson, The Law Behind Law: H, 29 Cor. L. REv, 285, 287 (1929); Molloy, Fletcher v. Rylands, A Reexamination of Juristic Origins, 9 U, of C피. L. REv. 266, 268 n.13 (1942); [Rylands rule; on the relation between the Rylands and the nuisance doctrines see Paton, Liability for Nuisance, 37 Irx. L. Rev. 1 (1942); Radin, supra note 6, 711]; Note, Absolute Liability for Negligence, it Notre DaMe Lawxer to (1941) (railroads).

8 Cooley, Problems in Contributory Negligence, 89 U. of PA. L. REv. 335, 351 (1941). But cf. HARPER, op. cit. supra note 1, 407. For a "moral" rationalization of workmen's compensation see Radin, supra note 6, 709.

9 PROSSER, TORTS 431.

10 Nichols v. Marsland (1875) L. R. 10 Ex. 255, 260.

11 Bostock-Ferari Amusement Co. v. Brocksmith, 34 Ind. App. 566, 73 N.E. 281 (1905).

See also Scribner v. Kelley, 38 Barb. 14 (N. Y. 1862); Prosser, TORTs 458.

12 Robinson v. Kilvert, 41 Ch. Div. 88, 94 (1889).

13 PROSSER, TORTS 458. 
less-no more. ${ }^{14}$ This "typicality" test, unlike the general "foreseeability" test of fault liability, delimits the liability for hazardous lawful activities as "one of the necessary burdens and expenses incident to such activities." 15

[§14.] (b.) With its liability for "ultrahazardous activities," the American Law Institute has taken a further and, potentially at least, decisive step towards the recognition of a new rationale of enterprise liability. Courageously abandoning the language of the traditional strict liabilities (where there is still much talk of presumptions of negligence or violations of duty), Section 519 of the Restatement advocates a new liability for foreseeable, though unavoidable, consequences of lawful, thougl hazardous, conduct. Under that provision:

one who carries on an ultrahazardous activity is liable to another whose person, land or chattels the actor should recognize as likely to be harmed by the unpreventable miscarriage of the activity for harm resulting thereto from that which makes the activity ultrahazardous, although the utmost care is exercised to prevent the harm. (Italics mine.)

This rule would admirably fit all kinds of mechanical enterprise if it could be applied to every ultrahazardous activity, defined in Section 520 as one which "necessarily involves a risk of serious harm to the person, land or cliattels of others which cannot be eliminated by the exercise of the utmost care." Under this formula a railroad would be liable for fire caused in a distant cottage by a spark from its engine. ${ }^{10}$ For, harm of this type was "likely" to result from this "unpreventable miscarriage" of its activity. On the other hand, the railroad would not be liable for the death of children drowned when chasing a kite across a frozen pond formed through the railroad's negligence. ${ }^{17}$ For, those facts which make a railroad's activity "ultrahazardous" (such as speed or emission of sparks) did not cause the children's death.

This rule, while not adopted by the courts, ${ }^{18}$ seems to express the

14 See HARPER, op. cit. supra note 1, 365. See also id. at 357, 392, 401.

15 Id. at 351 .

${ }^{16}$ See infra note 39 . No doubt there would be some limit to that distance which would be for the jury to determine.

17 See Part I, note 2.

18 Apparently the first case to impose liability under the Restatement doctrine where strict liability would not have been imposed previously, is Lutbringer v. Moore, $31 \mathrm{Cal}$. (2d) 489,190 P. (2d) 1 (1948). A fumigator was leeld liable for personal injuries caused by the escape of hydrocyanic acid gas. While talking extensively in terms of the Restatement, the case seems inconclusive in view of its ultimate reliance on the pre-Restatement case of Green v. General Petroleum Corp. 205 Cal. 328, 270 Pac. 952 (1928). Equally doubtful is the scope of Chapman Chemical Co. v. Taylor, 215 Ark. 630, 222 S. W. (2d) 820 (1949). Cf. Burns v. Vaughn, 216 Ark. 128, 224 S. W. (2d) 365 (1949). See in general Comment, 
missing rationale of the "negligence" liability of mechanical enterprise for unpreventable calculable harm. But Section 520 expressly excludes from the liability under Section 519 all activities which are a "matter of common usage." The scope of this exception is obscure. Oilwells are covered because "the dangers incident thereto are characteristic of oil lands and not of lands in general."19 On the other hand, railroads, and thus probably the very enterprise risks here discussed, are excluded as "of common usage" and, therefore, within the generally recognized domain of the negligence rule. Yet, in our search for a rationale of enterprise hability for negligence, the Restatement rule remains a significant attempt at formulating dormant thought.

[\$15.] (c.) Strict tort liabilities liave proved to be himited to liarm typically and calculably caused by a dangerous activity, and the Restatement liability for "ultraliazardous activities" is similarly determined. A further clue to the rationale of those liabilities can perliaps be gained by examining the liability for breach of contract which can be, and often has been, invoked to obtain strict liability in the absence of a tort rule to that effect. ${ }^{20}$ Under the classic case of Hadley $v$. Baxendale, ${ }^{21}$ damages for breach of contract are "sucll as may reasonably be supposed to have been in the contemplation of both parties, at the time they made the contract, as the probable result of the breach of it." ${ }^{322}$ Whether or not the scope of this rule "is much narrower than the 'proximate consequence' rule which prevails in actions to recover for tort, ${ }^{, 23}$ Hadley $v$. Baxendale, by relating the foreseeability test to the time of the making of the contract, rather than to the time of its breach, lias made a significant contribution to the understanding of the rationale of the entrepreneur's non-fault hability in general.

In thus limiting liability, the law, on the one liand, "manifests a policy to encourage the entrepreneur by reducing the extent of his risk, ${ }^{324}$

Absolute Liability for Ultrahazardous Activities: An Appraisal of the Restatement Doctrine, 37 CALIF. L. REv. 269 (1949).

19 Restateasent, Torts \& 520, Comment (e) (1938).

20 Although the contract rule reduces the scope of liability with regard to "privity" and punitive damages. See 5 Corban on ConTracts $\$ \$ 1019$, 1077 (1951). See also Seavey, supra note 6,444 . Election is facilitated by the uncertainty of the line between tort and contract law. See Prosser, ToRTs 201 ff., with references.

219 Ex. 341, 156 Eng. Rep. 145 (1854). For references to more recent cases see PATrERSON-Goble, CASES on Contracts 829 (1941); CoRben op. cit. supra note 20, $\$ 1007$.

22 Italics added. Hadley v. Baxendale, supre note 21, at 354, 156 Eng. Rep. at 151.

28 Patterson, The Apportionment of Business Risks Through Legal Devices, 24 Cor. I. REv. 335, 342 (1924). This has becone doubtful since Victoria Laundry (Windsor) Ld. v. Newman Industries Ld. [1949] 2 K.B. 528, 543; and Monarch S.S. Co. v. Karlshamns Oljefabriker (A/B) [1949] A.C. 196. See P.S. James, Measure of Damages in Contract and Tort-Law and Fact, 13 Mod. L. Rev. 36 (1950); Corbns op. cit. supra note 20, § 1019.

24 Patterson, supra note 23 , at 342 . Italics omitted. 
and, on the other hand, imposes on the entrepreneur liability for harm foreseeable by him as typical ${ }^{25}$ at the time of the start of his activity whether or not that harm was foreseeable by him or by his employee at the time of the causation by that employee of the particular harm.

While the contract rule can be directly applied only in those strict hability cases where, as in Hadley v. Baxendale and other common carrier cases, the damaging act is construed as a breach of contract, this rule remains meaningful even where no contract relation can be established. Here, the contemplation test may be related to a hypothetical "agreement" between the entrepreneur and the state, under which the enterprise is permitted or "licensed" in spite of its known dangerous nature, in consideration of the assumption of full liability for those, and only those, damages which "may reasonably be supposed to have been in the contemplation of both parties at the time they made the contract," that is, when the "license" was granted. ${ }^{26}$ Causation of such (typical) harm could be considered as bringing this "contractual" liability into operation whether or not the harmful event was preceded by "fault."

Liability contracts of this kind between entrepreneur and society have occurred in reality. A coal company had been granted permission by the city council to use explosives, on the undertaking to make good any damage to person or property arising from its dangerous activity. In a suit claiming damage to real estate the court held for plaintiff without proof of negligence because "by going ahead, defendant assumed that obhgation. ${ }^{227}$ In another case a construction agreement between a contractor and a municipal authority, under which the contractor assumed responsibility for all damage caused by blasting, was held to create strict liability to any third party injured. ${ }^{28}$ The contractual contemplation test to be applied in these cases in analogy to Hadley v. Baxendale is distinct from the traditional foreseeability test of the negligence rule and identical

\footnotetext{
25 See now Victoria Laundry (Windsor) Ld. v. Newman Industries Ld., supra note 23.

${ }^{26}$ Cf. SALMTOND, JURTSPRUDENCE, 456 (1922) according to whom certain activities are "tolerated only on the condition of making compensation to all who suffer from it"; and Bohlen, Fifty Years of Torts, 50 HaRv. L. REv. 725 (1937). The suggested analogy could perhaps be followed through also in another respect: Where the injurer has not obtained the prescribed license, i.e., where he has not concluded the "contract" providing for the imposition of a (strict but reduced) "enterprise" liability, his (full) liability for his "initial" negligence (in starting a dangerouls enterprise) has remained in force. Such a theory would rationalize those cases, now considered anomalous, which render the driver of an unlicensed automobile liable for injuries to another traveler without regard to causal fault ("Massachusetts rule"). See e.g., Capano v. Melchionno, 297 Mass. 1, 10, 7 N. E. (2d) 593, 598 (1937), and cases in Note, 163 A. L. R. 1375, 1392 (1946).

27 Baier v. Glen Alden Coal Co., 332 Pa. 562, 3 A. (2d) 349 (1939).

28 Coley v. Cohen, 289 N. Y. 365,45 N. E. (2d) 913 (1942). See also dissent by Finch, J. Phinney v. Boston Elevated R. R., 201 Mass. 236, 87 N. E. 490 (1909); Confreda v. George H. Flinn Corp., 68 N. Y. S. (2d) 925 (Kings Co., 1947).
} 
in result with the typicality tests of strict tort liability, and of the Restatement liability for ultrahazardous activities: Anticipation of harm at the time of the start of the activity rather than the time of the injurious conduct determines the scope of liability. It is this determination which reveals the rationale of the non-fault liabilities discussed: these liabilities are the price which must be paid to society for the permission of a hazardous activity.

\section{[§16.] 2. Enterprise Liabilities for "Negligence Without Fault."}

The failure of the law of strict liability to develop a common rationale and to resist the language and rationalization of fault liability may have been partly responsible for the fact that the "common sense of an industrial society" had to make its way within the law of neghigence "against minds steeped in the absolutes of a once common law."29 However, beginnings just discussed of a new understanding of non-fault liabihty should gain new force in the entire law of enterprise liability at this time, when that other reason for the repression of strict liability, the desire to protect the growing industry, seems outweighed by the wealth of corporate enterprise and its ability to distribute its cost by liability insurance and price calculation.

In fact, as has been shown, ${ }^{30}$ the scope of the negligence liability of enterprises not strictly liable has approached that of a strict liability for typical causation, and the similarity between both types of liabilities as to their rationale has become increasingly obvious: Exposing the community to risk, rather than causation of the individual harm has become the basis of liability in both fields, ${ }^{31}$ even in countries in which fault has been called "the mother of all enterprise liability."32

The similarities between the fault and non-fault liabilities of modern enterprise regarding their basis and rationale justify a similar theoretical analysis. The contract analogy seems applicable to both types of liability if a promise by the entrepreneur is assumed to indemnify anybody "typically" injured by the enterprise; a promise made in consideration of the toleration of the "initial negligence," committed by starting the dangerous enterprise. ${ }^{33}$ Closely akin to the contract analogy is the theory of "assumption of responsibility," proposed for the "manu-

20 Hamilton, The Living Law, 26 SURVEX GRAPHCC 632, 635 (1937).

${ }^{80}$ See Part I, §§ 5, 8.

81 Prosser, Torts, 429. See also Seavey, Principles of Torts, 56 Harv. L. Rev. 72, 86 (1942).

82 Croissant, Haftpflicht UNd Eigenes Verschulden, 35.

83 See Spirrem, Le Contract d'Assurance de Responsabitité Civile (1934) 23: “The guaranty of indemnification for all damage done is the consideration for the risks imposed upon others by dangerous things" (translation, italics added). 
facturer's" liability in Section 16-B of the Revised Second Draft of the Uniform Sales Act. ${ }^{34}$ That calculability of the harm should be, and to some extent is, the proper test of both strict and "quasi-strict" liabilities has probably found its most striking expression where liability is made to depend upon the existence of liability insurance. ${ }^{35}$

Frequently railroads and automobile operators are, under the negligence rule, "really" not held for a particular "fault" occurring in their operations, but, as under rules of strict liability, for the inevitable consequences of their dangerous activities whicls, but for their being tolerated because of a superior interest, would be "negligent" because of being foreseeably harmful. In this sense this enterprise liability for "negligence" is "strict" in that it is imposed on lawful rather than on reprehensible conduct; and the purportedly required "negligence" in the railroad engineer's or automobile driver's incorrect reaction is reduced to a mere vehicle of a "quasi-strict" liability for dangerous enterprise.

The entrepreneur's duty to pay damages for an injury, from the inflicting of which he lias "a riglt not to be prevented,"30 is analogous to the results of the rule permitting but sanctioning the infliction of harm by "necessity." This analogy has more than dogmatic siginificance. In both situations-to use Professor Bohlen's formulation-"it is obviously just that he whose interests are advanced by the act should bear the cost of doing it," thougli "the interest of the actor which is served by his act may, as compared with that which is necessarily or probably invaded by it, be of such value that he slould not be punished, and that resistance slould be discouraged by imposing liability upon one who resists."137 Both the navigator who is permitted on grounds of necessity to moor his vessel to a private wharf, ${ }^{38}$ and the railroad which is permitted an activity in-

34 Report and Second Draft, The Revised UnIform Sales Acr (1941). Section 2-315 of the 1950 Draft of a Uniform Commercial Code has restored the conventional language. See supra Part I, note 109.

35 See Part I, \& 6.

36 Marceau, Reflections on the Theory of Negligence, 5 LA. L. REv. 495, 506 (1944), using Hohfeld's terminology.

37 Bohlen, Incomplete Privitege to Infict Intentional Invasions of Interests of Property and Personality, 39 Harv. L. Rev. 307, 316 (1926). See also Prosser, Torts 139.

38 Vincent v. Lake Erie Transportation Co., 109 Minn. 456, 124 N. W. 221 (1910). See also Ploof v. Putnam, 81 Vt. 471, 71 Atl. 188 (1908); Depue v. Flatau, 100 Minn. 299, 111 N. W. 1 (1907); Marceau, supra note 36, 506; Prosser, Torts, 139; Restatement, Torts $\$ \S 296,470$ (1934); WINFIELD, LAW of TORT 55 (1946). In automohile cases something like a general theory of the "agony of collision" seems to be in the making. Johnson v. Prideaux, 176 Wis. 375,187 N. W. 207 (1922). See also HUGHES, ROAD USERS' RTGHTS, LIABHITY AND INSURANCE, 38 (1938); 1 HARPER, READINGS IN TORTS, 320, 334 (1941). For a collection and discussion of the authorities see Carpenter, Proximate Cause, 14 So. CAx. L. REv. 1, 115, 416; 14 So. Car. L. Rev. 187, 304, 427; 16 So. Caz. L. Rev. 1, 61 (1940-1943); Evans, The Standard of Care in Emergencies, $31 \mathrm{Kx}$. L. J. 207 (1943). This problem has been given 
evitably resulting in the emission of sparks into private property, may not be resisted in their lawful activities, but they must, within the limits to be discussed presently, pay damages for any harm so caused.

This, of course, does not mean that the railroad or the automobile operator could or should never be held for fault. Where the victim has proved the engineer or the driver to have caused the injury by an act of carelessness, for instance, by reading a newspaper instead of watching the road, negligence hability will obtain under the same rule that would apply to a person who carelessly fired a sliot in a city street. Only that type of "negligence" consisting in a technical error, which, thougli often artificially construed and concluded from surrounding circumstances, usually supports present-day enterprise liability for inevitable accidents, requires, I believe, the new rationale.

The need for this rationale appears even more clearly in the courts' attempts at determining the scope of this enterprise hability for so-called "negligence." The "foreseeability" test as generally used has proved inapplicable. Where a railroad engineer had "negligently" run his train into a landslide which, a few minutes before (after another train had passed undamaged), had blocked the tracks, it is to mislead the jury to ask it whether the engineer "could have anticipated the burning of the plaintiff's property," several liundred feet away, by oil ignited on the train by the impact and carried to that property by an adjoining, suddenly swollen creek. $^{89}$ And it is to mislead court and jury to ask whether the foreman who inadvertently failed to keep open the culvert should have reasonably foreseen that children chasing a kite across a frozen pond formed by water from that culvert, would be drowned. ${ }^{40}$ This is not and cannot be the issue for the railroad's hability. What the law wants to know is whether liability can be fairly imposed on the railroad in those cases because the harm was typical for its activities, and thus calculable and reasonably insurable. This typicality test is the one adopted in the law of strict liability. ${ }^{41}$ It is the one suggested by the American Law Institute for its ultrahazardous activities ${ }^{42}$ and it is the one that slould be consciously

much attention in Continental legal literature. See the writer's MisTake AND UNLAWFuLNESS (IRRTUM UND RECHTSWDRIGEEIT) (1931), and TORT LIABIITY FOR FAULT (SchULDHAFTUNG IMr SCHADENERSATZRECHT) (1936) $198 \mathrm{ff}$; Assurance Oblige, supra Part I, note 1, at 445 et seg.

30 Hoag v. Lake Slore and M.S. R. R., 85 Penn. St. 293, 27 Am. Rep. 653 (1877). While the court in this case denied liability because of lack of a "proximate cause," defendant railroad was lield liable on substantially identical facts in Kuhn v. Jewett, 32 N. J. Eq.

(5 Stew.) 647 (1880).

40 See Part I, $\S 1$.

41 See supra $\$ 13$.

42 See supra $\& 15$. 
recognized in the law of the "quasi-strict" liability of mechanical enterprise for negligence. That courts are groping for this solution is frequently apparent in their treatment of the requirements of "proximate cause" and "due care."

Where a ship and its cargo were destroyed by an explosion of petrol vapor caused by a spark emitted by a plank "negligently" dropped into the hold of the slip, the charterer's liability was not "really" based on the proximate causation or foreseeability of larm by the workman who negligently dropped the plank; ${ }^{43}$ but, I believe, on the consideration that a cliarterer can calculate as typical (and can insure against) the loss by fire of a petrol cargo.

Standing on a railroad platform, Mrs. Palsgraf was injured by scales broken in a concussion caused by fireworks exploding at a considerable distance in a package which had been "negligently" dislodged from a passenger's arm by a railroad employee assisting the passenger in boarding the train. Few will quarrel with the decision denying the railroad's liability. ${ }^{44}$ Yet, how close did Cardozo's majority opinion come to reality when he reasoned that defendant's employee could not reasonably lave foreseen damage to the plaintiff? ${ }^{45}$ And low close to this reality is Andrews in his dissent when he pleads for unlimited liability for all acts which unreasonably threaten the safety of others? ${ }^{46}$ Was not the real test, with opposite results, consciously or nonconsciously applied by both Cardozo and Andrews, whether the plaintiff's injury was typical and thus calculable and insurable by the railroad? True, the answer in this case and in many other cases would not be easy even if the issue were so phrased. But neither juries nor judges should be misled by talk of "proximate" or "direct" cause, "due care," "duty to foreseeable plaintiffs," or "intervening forces." Only by relating the consequences to the enterprise activity itself rather than to the individual causative act, can liability be restricted "to the scope of the original risk created," that is, to the "negligence without fault" inherent in the conscious assumption of a risk to be created by a lawful but dangerous activity.

43 In re Polemis and Furness, Withy \& Co., [1921] 3 K. B. 560, 575.

44 Palsgraf v. Long Island R. R., 248 N. Y. 339, 162 N. E. 99 (1928).

45 Palsgraf v. Long Island R. R., supra note 44 , at 345,162 N. E. at 101. Cf. the writer's Note, Loss-Shifting, Part I, note 1; Wilson, Some Thoughts about Negligence, 2 OrfA. L. Rev. 275, 284 (1949).

46 Palsgraf v. Long Island R. R., supra note 44, at 350, 162 N. E. at 101.

47 Prosser, Torts 342. Perhaps the questions raised id. $343 \mathrm{n} .63$ as to the himits of hability of a railroad for operating a train without a proper lookout can thus be more readily answered: Collision with a cow on the tracks is clearly within the "scope of risk," in contrast to electrocution of a man ten miles away caused by the twisting of a power line. See also Prosser, Proximate Cause in California, 38 CarIf. L. Rev. 369, 397 (1950). 
The close relationship in rationale and scope between "negligence" and strict enterprise liabilities does not require, however, the legislative removal from all enterprise liability of the language of negligence, "distressingly inadequate" 48 as this terminology may have proved to be. No one formula can provide for the manifold facts requiring different limitations of liability in each case. Even countries which liave adopted strict liability statutes for enterprise liazards liave not been able to avoid the problems of "proximate causation" or "violation of a duty of care." And the common sense of juries is probably the best judge where the law cannot give more than a vague guidance. But one thing we owe to both judges and juries: to assist, rather than to hamper them in applying their common sense. If we mean to ask the jury whether a certain harm caused by hazardous but lawful enterprise activities can be justly imputed to the entrepreneur as being reasonably calculable and insurable by him, we must not ask the jurors wliether in their opinion a reasonable man in lis employee's place slould have avoided the causation of that harm. No longer sliould "the conduct of one man [be] elaborately investigated in order to determine and fix the liability of another man." ${ }^{\prime 9}$

Without legislation the necessary clarification can perhaps be achieved by distinguisling within the law of "negligence" between a liability based on the censure of reprehensible conduct, on the one hand, and a liability for the unavoidable and insurable consequences of lawful (enterprise) activities, on the other hand. These two types of hability could be distinguished as liabilities for "moral negligence" and "negligence without fault." This distinction would stress the non-fault character of initially "negligent" but lawful dangerous activities as opposed to unlawful negligent conduct, and would make it possible to discriminate between the "foreseeability" test of a liability for moral negligence and the typicality test of a quasi-strict liability for lawful dangerous activities.

Liability for "negligence without fault" can be no more sharply defined than neghigence liability as defined above; ${ }^{50}$ but it may rouglily be said to be connected with those initially dangerous activities which, while legalized because of their social value, are held to strict liability in terms of the neghigence rule. This liability may be said to include injuries which, being typical for the particular enterprise, could have reasonably been foreseen (thougli not avoided without abandoning the enterprise) by the entrepreneur when starting his activity. ${ }^{51}$

48 Green, Are There Dependable Rules of Causation?, 77 U. of PA. L. REv. 601, 620 (1929).

49 Ballantine, A Compensation Plan for Railway Accident Claims, 29 HARv. L. Rev. 708 (1916).

50 Part I, \& 9.

51 That the word "negligence" is preserved in the terminology proposed could gain 


\section{B. Fault and Non-Fault Liability for Negligence Distinguished and Reconciled: Summary and Outlook}

\section{[§ 17.] 1. The Scope of Liability}

Two motorists collided, and one car was propelled into a building. Some time later when the car was removed, a stone loosened by the accident fell from the building and killed a pedestrian. The two motorists (or rather their insurers) were held hable for the pedestrian's death. The court argued that the defendants must have foreseen that the vehicle would have to be moved from the structure, that parts of that structure would fall into the highway and that a passing pedestrian might be injured." In another case a motorist was injured by a defective pillar (belonging to the defendant city) against which his car had been thrown in a collision. The court held for defendant who could not have foreseen "that a car might have been struck by another car in such a way as to cause it to come in contact with the pillar and cause the pillar to fall." suggested above that the "foreseeability" test, which is so clearly unrealistic in these and in innumerable similar cases, becomes meaningful if related to the hazardous activity as such rather than to the causative conduct; or, in other words, if the test of individual foreseeability is replaced by a test of general "typicality." While death of a pedestrian near the place of collision (without regard to intervening atypical occurrences) is typical of the hazards of driving automobiles, injury to a motorist running against a pillar is not typical of the enterprise risks of a municipality responsible for the maintenance of pillars. In most cases this typicality test would merely rationalize otherwise unexplainable commonsense "foreseeability" decisions of judges and juries. Occasionally, however, (as will be illustrated in the next sections), if consciously applied, it might lead to more desirable results than the misleading language about the "reasonable man's" foresight.

The substitution of typicality for foreseeability would also, I beheve, cure or, at least, mitigate, the present anarchy in the determination of the amount of damages for bodily injury and death claims in enterprise bability cases. That the need for reform is imcreasingly recognized is apparent in the insurers' practice of fixing policy maxima and standards of recovery, and in numerous attempts of commercial digests to categorize jury assessments. ${ }^{54}$

particular significance where a financially irresponsible injurer turns his initial "negligence without fault" into a "moral," perhaps even criminal negligence by not keeping his "promise" to secure indemnification to the injured by insurance or otherwise. See infra note 80 .

52 In re Guardian Casualty Co., 253 App. Div. 360, 2 N. Y. S. (2d) 232 (1938).

58 Leachman v. Louisville, $270 \mathrm{Ky} .260,263,109 \mathrm{~S}$. W. (2d) 614, 615 (1937).

54 See, e.g., 15 Friftri DecennaA, Digest (1936-1946), Title "Danages," VII (176 pages). 
Full stability and clarity in the solution of this question, as in that of many other questions of arithmetical computation, could, of course, be obtained only by statutory reform which, by introducing "tariffs" of recovery, would thus return to the oldest tort law. ${ }^{.5}$ Unless and until statutory schemes of a standardized compensation for injuries typically caused by hazardous activities replace the present common law system of individual jury assessment, some progress could probably be achieved by instructions assisting, rather than misleading, juries in their difficult task. Such instructions would have to be based on the conscious distinction within the law of negligence between enterprise habihity for harm calculably and inevitably caused by enterprise hazards ("neghgence without fault") and what is left of a "moral" neghigence liability for the foreseeable consequences of reprehensible conduct. For, on the one hand, in cases of the latter type, jury assessinent should continue to take into account degrees of the injurer's fault and possibly the relative financial capacities of the parties. On the other hand, consideration of the injurer's circumstances has no place in a hability for "negligence without fault.".56 With regard to that hability, in the absence of legislation, substitution of the typicality for the present foreseeability test would serve both the injured, who could expect compensation by more uniform awards, and the injurer, who could more easily calculate his liability based upon this very calculability.

\section{[§ 18.] 2. The Plaintiff's Choice}

The proposed distinction would appear in the first place in the plaintiff's pleadings and in the charge to the jury. In cases where the harm caused by a hazardous enterprise activity was both "typical" for that activity and "foreseeable" at the time of the causative conduct, the plaintiff should have the riglit to choose between claims based on fault or non-fault. If he can prove foreseeability he will choose the first count under which he could hope to recover full damages and need not sliow typicality of the harm. If he shuns the foreseeability issue he will, on the other hand, base his complaint upon a theory of negligence without fault, resigning himself to the typicality limitations of that theory.

The charge to the jury will correspond to the plaintiff's choice. Where, as would ordinarily be the case, neghigence with and without fault would be alleged in the alternative, the jury would be charged somewhat as follows:

1. The defendant is liable for "morally" negligent causation of the harm:

\footnotetext{
${ }^{55}$ See, e.g., 2 Poitocri-Matriand, History of Enguism Law, 525 (1895). But see also supra Part I, notes 8, 158.

56 As to the plaintiff's choice, see infra $\S 18$.
} 
(a) if he is guilty of conduct which a reasonable man would have been expected to avoid (except for mere faulty reactions covered by instruction 2); and

(b) if he could have reasonably foreseen that harm of the type actually caused would result from such conduct.

2. The defendant is liable for "negligence without fault":

(a) if the harm was caused by an innocently negligent ("quasineghigent") activity, i.e., an activity initially negligent but legalized because of its social value (certain activities, such as the operation of railroads or automobiles being quasi-negligent in that sense as a matter of law); and

(b) if the harm was of a kind which could have been calculated (and therefore insured against) as typical for the particular enterprise.

No doubt, this charge too would leave room for many ambiguities and errors, but no longer would the judge (though he may not himself be misled by using misleading words), mislead the jury. ${ }^{67} \mathrm{~A}$ pedestrian is injured by a brick projected by a passing truck. $A$ jury which denied recovery, ${ }^{58}$ presumably because it was reluctant to find the driver negligent, might have been willing to hold for the plaintiff on a finding of negligence without fault, that is, causation of harm typical for the hazards of driving a truck. A tubercular woman claims damages for suffering caused to her by smoke that had spread to her cottage from a railroad fire. A jury which, under the court's charge, felt compelled to hold the railroad for neghigence, ${ }^{59}$ might have denied such extraordinary liability if it had been asked whether such harm was typical for the hazards caused by the operation of railroads.

\section{3. "Third-Party Tortfeasors"}

By the toleration of its "negligent" activities, enterprise has been immunized against the rule sanctioning the avoidable causation of harm foreseeable at the start of those activities. However, under that very rule, such enterprise has been made liable in many situations through the medium of a "third-party tortfeasor," such as the employee under

${ }^{57}$ Edgerton, Negligence, Inadvertence, and Indiference: The Relation of Mental Stales to Negligence, 39 Ftarv. L. REv. 849, 870 (1926). See in general Note, Instructions to the Jury in Negligence Cases, $28 \mathrm{Ky}$. L. J. 469 (1940); HoGHEs, THE LAW OF Instructions to JURIES (1905); James, Functions of Judge and Jury in Negligence Cases, 58 YALE L. J. 667 (1949); Note, Proximate Cause-Confusion of Jutrors by Misleading Label, 34 MArQ. L. REv. 204 (1951).

58 Demjanik v. Kultau, 242 App. Div. 255, 274 N. Y. Supp. 387 (1934).

59 Missouri Pac. R. R. v. Johnson, 198 Ark. 1134, 133 S. W. (2d) 33 (1939). By eliminating the foreseeability issue, more realistic and consistent answers could perhaps be obtained to the much litigated question as to the liability of automobile operators to onlookers of accidents for shock mjury. See Seitz, Duty and Foreseeability Factors in Fright Cases, 23 MARQ. L. REv. 103 (1939). 
the doctrine of respondeat superior, ${ }^{60}$ the operator in automobile liability, ${ }^{61}$ the retailer in products liability, ${ }^{62}$ or the trustee in the trust estate's liability for torts. ${ }^{63}$ The relation of this device to the proposed theory of negligence without fault will now be examined.

[§19.] (a.) Employer and employee. Respondeat Superior. Many theoretical and practical difficulties could probably be clarified by conceiving the entrepreneur-master's liability primarily as one for harm typically and unavoidably caused in his lawful enterprise, rather than a liability for harm avoidably and foreseeably caused by a servant's reprelensible conduct. ${ }^{64}$ No longer would we require an apology for rejecting the master's defense that lie has carefully chosen and controlled his negligent servant. ${ }^{65}$ No longer would an independent contractor's intervening act or the plaintiff's contributory negligence ${ }^{66}$ be either needed to relieve the employer of a liability atypical for the hazards of his enterprise, or sufficient to preclude recovery against him for harm typically caused by those liazards. Nor would an obsolete rationale compel loolding the employer for punitive damages imposed on a morally negligent employee ${ }^{67}$ or denying the entrepreneur recourse against other "tortfeasors" "because the law does not lielp the wrongdoer." ${ }^{288}$

Moreover, the employer's liability for the negligence of employees non-suable for, or acquitted of, that very negligence, now an erratic doctrine of a small minority and hardly tenable under the prevailing theory of negligence, could become the rule without legislative interference. Two cases may illustrate these minority doctrines. ${ }^{69}$

Where an automobile accident liad been caused by a plank placed across the road by a highway district in the course of construction work, a jury verdict against the district was upheld notwithstanding a sinultaneous verdict in favor of the foreman for whose negligence the district was held. ${ }^{70}$ The court quoted with approval from decisions of other

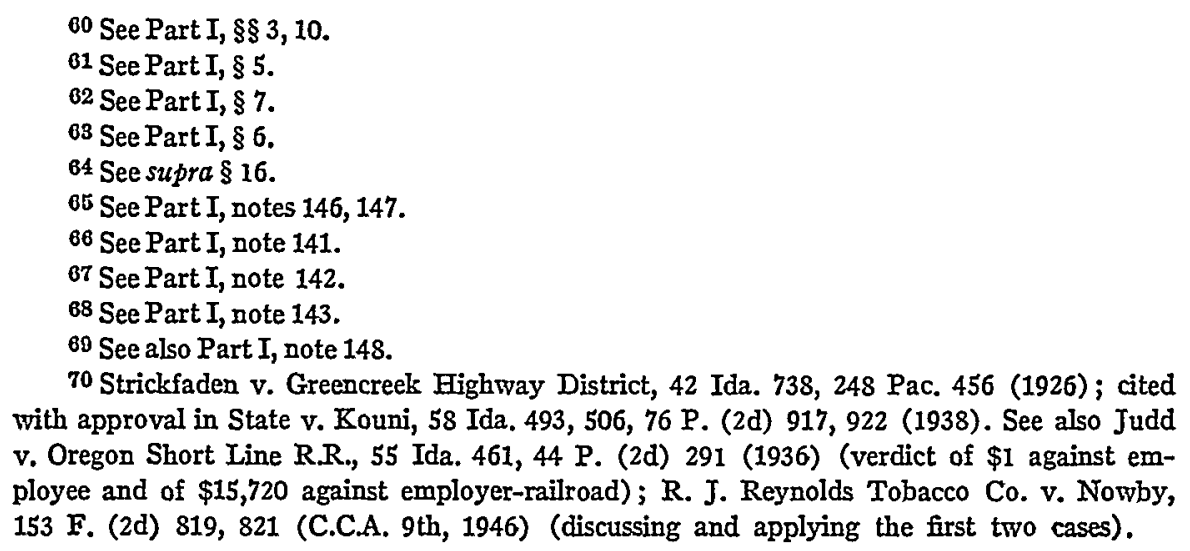

70 Strickfaden v. Greencreek Highway District, 42 Ida. 738, 248 Pac. 456 (1926); cited with approval in State v. Kouni, 58 Ida. 493, 506, 76 P. (2d) 917, 922 (1938). See also Judd v. Oregon Short Line R.R., 55 Ida. 461, 44 P. (2d) 291 (1936) (verdict of $\$ 1$ against employee and of $\$ 15,720$ against employer-railroad); R. J. Reynolds Tobacco Co. v. Nowby, 153 F. (2d) 819, 821 (C.C.A. 9th, 1946) (discussing and applying the first two cases). 
jurisdictions substantially arguing that one cannot exonerate oneself by referring to an inconsistent decision concerning another party. ${ }^{71}$ Other courts have admitted this rule to be "illogical" and defended it simply on grounds of justice. ${ }^{72}$ But occasionally the true "logical" reason underlying this practice appears in a dictum such as that of the Mississippi Supreme Court which sees the master and the servant liable "on distinct and different legal principles-the engineer, because of his personal trespass; the railroad company, because of its failure to discharge its non-delegable duty to the public regarding the custody and management of its dangerous instrumentalities. ${ }^{373}$ Stripped of its duty language, this statement amounts to the recognition of an entrepreneur's hability for negligence without fault "distinct and different" from the employee's liability for fault. Even more significantly the Idaho court upleild a verdict assessing damages of over $\$ 1$ against a railroad engineer and of over $\$ 15,000$ against his employer, on the ground that, "although the jury found that the engineer was guilty of neghigence, it is not at all surprising if they concluded that, since what he was doing was for the nuaster and could not profit him in any way beyond his wages, it would be only fair for his employer to pay whatever damages had resulted from the negligent acts committed." 74

Another minority doctrine exemplifying the occasional recognition of an independent rationale of the employer's liability, is that expressed in a decision of the New York Court of Appeals in which a woman was permitted to recover against her husband's employer for injuries negligently inflicted on her by her husband within the scope of his employment, although under New York law she could not lave maintained an action against her husband. ${ }^{75}$ Under the prevailing analysis this holding

71 Texas \& P.R.R. v. Huber, (Tex. Civ. App.) 95 S. W. 508 (1906) [approved in S. H. Kress \& Co. v. Hall (Tex. Civ. App.) 154 S. W. (2d) 278 (1941) ]; Whitesell v. Joplin \& P.R.R., 115 Kan. 53, 222 Pac. 133 (1924) [cited with approval U.S. v. Marcus, 41 F. Supp. 197, 215 (Pa., 1941) ]; Ill. Centr. R.R. v. Murply's Adm'r, 123 Ky. 787, 798, 97 S. W. 729, 732 (1906) [since overruled, see now Chesapeake \& O. R.R. v. Williams' Adm'x, $300 \mathrm{Ky}$. 850, 190 S. W. (2d) 549 (1945) ]. See also St. Louis \& S.F.R.R. v. Sanderson, 99 Miss. 148, 54 So. 885 (1911) [cited with approval Miss. Power \& Light Co. v. Smith, 169 Miss. 447, 463, 153 So. 376, 379 (1934); without disapproval in Granquist v. Crystal Springs Lumber Co., 190 Miss. 572, 584, 1 So. (2d) 216 (1941) ]. Occasionally courts have relied on the fact that neither the pleading nor the evidence had been limited to one particular employee. See Elgin v. Kroger Grocery \& Baking Co., 357 Mo. 19, 206 S. W. (2d) 501 (1947) with additional references.

72 See De Sandro v. Missoula Light \& Water Co., 48 Mont. 226, 136 Pac. 711 (1913), stating that the plaintiff should not be deprived of his right of recovery on purely technical grounds. But $c f$. Lowney v. Butte El. Co., 61 Mont. 497, 204 Pac. 435 (1922).

73 Ill. Centr. R. R. v. Clarke, 65 Miss. 691, 697, 38 So. 97, 98 (1905). See supra note 71.

74 Judd v. Oregon Sliort Line R.R., supra note 70, at 58 Ida. 478, 44 P. (2d) 298. Italics added. See supra note 70.

75 Schubert v. Schubert Wagon Co., 249 N.Y. 253, 164 N.E. 42 (1928). 
can hardly be defended against the reasoning advanced in decisions to the contrary, that where the agent is not liable the principal cannot be held, since if lie were so held, the agent's immunity would indirectly be destroyed by the principal's recovery over against the agent. ${ }^{76}$ But if respondeat superior is no longer interpreted as merely transferring to the master a servant's hability for the repreliensible causation of foreseeable harm, but recognized as creating in the master an independent liability for harm typically caused within his lawful enterprise, the master's hability in such cases is easily justified. He will be held for calculable liarm without regard to the occurrence of reprehensible conduct. Where the master's liability is based on a mere inadvertence of his servant, an attempt by the master to recover from his servant will hardly be successful. And where the latter has been guilty of reprehensible conduct his obligation to indemnify the master can be explained by the "breach of an independent duty." "7r

Not always is it expedient to distribute enterprise losses through the employer, as where the agent rather than the master is the entrepreneur best able to foresee and calculate losses typically and inevitably caused by his activity. This is particularly true where the agent serves several masters rather than one. To rationalize in such cases the denial of the entrepreneur's liability, courts have developed the rule of the "independent contractor" for whose actions the master is not hable. The difficulties in the application of this rule have proved insurmountable notwithstanding many attempts to save it by additional artificial theories. ${ }^{78}$

Professor Seavey assumes that the law is moving towards the abolition of the independent contractor. ${ }^{79}$ Indeed, the entrepreneur's "control" of his agent's activity should determine the distribution of the loss only if to increase the effectiveness of such control were the primary purpose of the doctrine. While this is not the case, this doctrine can perhaps be preserved and made to serve a rational purpose once respondeat superior is understood as a device for the imposition of a non-fault liability for calculable liarm. Upon this assumption, the entrepreneur slould be liable

${ }^{76}$ See Riegger v. Bruton Brewing Co., 178 Md. 518, 16 A. (2d) 99 (1940).

77 See Schubert v. Schubert Wagon Co., supra note 75 at 257,164 N. E. at 43 . See also Prosser, Torts 909. See also Smith v. Foran, 43 Conn. 244, 21 Am. Rep. 647 (1875); Note, 26 MINTr. L. Rev. 730, 731 (1942).

78 Concerning the theories of "control and selection" and of "implied authority" see e.g. Douglas, Vicarious Liability and Administration of Risk, 38 Yạ.E L. J. 584, 720 (1929); Steffen, Independent Contractor and the Good Life, 2 U. OF CHI. L. Rev. 501 (1935); Harper, The Basis of the Immunity of an Employer of an Independent Contractor, 10 Inv. I. J. 494 (1935). For an analysis of New York cases see N. Y. STATE LAw Revuston CossSIISSION, REPORT (1939) 409-642, Liability of Employer for the Negligence of an Independent Contractor; and in general Note, 8 A. I. R. (2d) 267 (1949).

79 Seavey, supra note $6,456$. 
only and always if he can calculate the harm likely to be caused by his enterprise and is thus in a position to insure against liability for such harm. If his contractor, too, is in such position, he should be jointly liable, while claims against him for indemnity could, unless stipulated, be limited to "moral" fault. True, this would leave the burden on the entrepreneur where the contractor is neither insured nor financially responsible. But this result is sound in that it will induce insurance of insurable loss. Occasional attempts to hold employers for the employment of financially irresponsible contractors would thus find a rational basis. ${ }^{80}$

While the doctrine of the independent contractor has been used to isolate the entrepreneur against babilities which he could not be expected to calculate and insure against, the "scope of employment" doctrine has been used or abused to extend the entrepreneur's liability to all calculable harm without regard to technical qualifications of the servant's causative conduct as within or without his authority. The word "servant" has thus cone to mean -in Professor Seavey's words-no more "than a person for whose physical acts under specified conditions the master is responsible" and the doctrine has lost its usefulness as a test for the distribution of enterprise losses.

Since human beings are not machines the entrepreneur's liability can obviously not be limited to acts strictly within the necessary activities of the enterprise. On the other hand, equally obviously, not all conduct of every agent of the enterprise can be imputed to the entrepreneur. Courts have been inclined to deny the employer's hability for the servant's "frolic." Yet, since some harm from a normal number of frohics is part of the hazards of the enterprise, courts have been urged to bear in mind the risk-spreading justification of the doctrine of respondeat superior and to "reach conclusions which will further the policy upon which the justification rests." ${ }^{12}$ The issue is not whether the servant intended to act within his employment, ${ }^{83}$ but whether "in view of what the servant was actually employed to do, it was probable that he would do what he did"84 or, in other words, whether his harmful conduct was typical for the enterprise in which he was employed.

80 See Lawrence v. Shipman, 39 Conn. 586, 590 (1873): "If a person having an interest in a job which naturally exposes others to peril, should attempt to shield himself from responsibility by contracting with a bankrupt mechanic, I think the employer might be subjected for damages done by the contractor. ..." The plaintiff had claimed that the employment of a person financially irresponsible was equivalent to the employment of an incompetent person. It seems feasible that future courts on similar grounds will hold an employer for having employed an uninsured contractor.

81 Seavey, supra note 6,465 n.49.

82 Y. B. Smith, Frolic and Detour, 23 Cor. L. REv, 444, 460 (1923). See also id. at 724.

33 See Gleason v. Seaboard Air Line R. R., 278 U. S. 349, 49 Sup. Ct. 161 (1929); Y. B. Smith, supra note 82, 724.

84 Y. B. Smith, supra note $82,724$. 
Finally, and perhaps most significantly, under a rationalization of enterprise liability as of a liability for negligence without fault, the existence or availability of liability insurance could take its rightful place. That the harmful activity was insured or could have been insured, should be recognized rather than concealed as a decisive factor in the jury's finding of negligence without fault. ${ }^{85}$ What is now referred to as the "prejudicial effect" on the jury of its knowledge of insurance would thus appear as a legitimate basis of its findings. And the apparent paradox of an immune entrepreneur forfeiting his immumity by taking out insurance could become an integral part of our tort law. Non-suable charities, infants, spouses, and parents ${ }^{86}$ could be included in future general schemes of loss distribution.

[§20.] (b.) Owners and operators of automobiles. In many countries the automobile owner is hable as such for the damage caused by his "enterprise." ${ }^{\prime 87}$ While the French courts have reached this result by a rather artificial extension of the liability for inanimate things, ${ }^{88}$ fault presumptions have been used in Argentina, Austria, Finland, and Italy, and express statutory provisions have been enacted elsewhere. ${ }^{89}$

In this country automobile hability followed the pattern of the railroads' liability for negligence. ${ }^{90}$ As in the law of railroad liability the need for the substitution of the entrepreneur's liability for that of an often financially irresponsible actor has produced many artificial devices.

85 See Part I, note 156.

${ }^{86}$ See Part I, notes 153-155.

87 See Société des Nations, Institut International pour l'Unification du Droit Privé, Responsabilité Civile des Automobilistes, Etude Préliminaire, 28 (1935); Unification Internationale en Matière de Responsabilité Civile et d'Assurance Obligatoire des Automobilistes 18, 19 (1940); JaNNOTT, KRAFTFAHR-ZEUGHAFTPFLTCET-RECET UND VERSTCEERUNG IM InUNd AUsLaNd (1937); Deak, Liability and Compensation for Automobile Accidents-A Survey of Foreign Legislation, 21 MINv. L. Rev. 123 (1937). Most laws hold the "owner" liable (Finland, Italy, Norway, Sweden). But others are satisfied with some measure of control. See the "Halter" in Germany, the "Betriebsunternehmer" in Austria, and the "detenteur" or "guardien" in France.

88 Article 1384 (1) of the French Civil Code provides in part for the hability for harm caused by "those things one has in his custody." This article, though but a restatement of the Roman liability for things dangerously placed (e.g. on a window), was "discovered" for the purpose of rationalizing the liability of mechanical enterprise by the Belgian scholar Laurent [Prnncipes Du Drorr Crver FrançaIs, t. XX, No. 639] and has since been apphed for that purpose hy the courts [See the celebrated decision of the Chambre Civile of June 11, 1896, S. 1897, 1.17]. This judicial legislation was recognized and confirmed by the Law of November 7,1922 by an amendment of Article 1384 (1). For a full discussion and references to the abounding writings in this field, see 2 MazeaUd, Responsabmiré CIVIEE 2 et seq., 220 et seq. (4th ed., 1949). For South American law see e.g., OrGaz, ResponsabLDDAD POR EL HECHO DE LAS COSAS INANTMAadas (1931).

80 See in general Maurice Picard, Pour une loi sur la réparation des accidents d'automobiles, Rev. GeN. Ass. TERR. (1931) 613; Gorphe, La responsabilité du fait des automobiles en droit comparé etc., REV. CRIT. LeGrs. ET JURIS. (1935) 150.

80 See Part I, \& 6. 
In the field of automobile liability, however, the popular feeling that the owner is more likely to pay than the driver and that he who originates danger by setting a car upon the highway should be responsible, ${ }^{01}$ has not, apart from statutes, produced a general vicarious liability of the owner. ${ }^{22}$ Only where the owner had in fact retained control over the operation of the car or where a presumption of such control is based on his presence in the car, has such liability been established. ${ }^{03}$ While the admonitory policy underlying this himitation is obvious ("you shall watch your driver"), the related "family purpose doctrine" submitted, an expression of a developing primarily compensatory trend. Under that doctrine the car owner is hable for liarm caused by a member of his household in driving the car with his permission or acquiescence. ${ }^{25}$ Rationalizations in terms of the current terminology must fail. Liability is neither based on fault nor on a master-servant relationship. The true rationale of the doctrine appears, I believe, in its limitation to harm done by a car operated for a "family purpose." Broad interpretations of this requirement as imcluding driving for the driver's own pleasure, indicate that what is intended is the himitation of this liability for "negligence without fault" to harm typically caused in the owner's "business" as a householder ${ }^{98}$ This test should replace, under this doctrine as under similar statutory rules, ${ }^{97}$ the common foreseeability test which has caused difficulties similar to those arising under the "scope of employment" rule of respondeat superior..$^{98}$ Ouly the extension of the owner's liability to unauthorized use might require legislation, though there are many indications for a return of the "dangerous instrument" doctrine. ${ }^{90}$ Recognition

\footnotetext{
91 PROSSER, TORTS 499.

92 Early attempts in that direction have remained isolated. In Sleath v. Wilson, 9 Carr \& Payne 607, 173 Eng. Rep. 976 (1839) the owner of a carriage was held liable in a frolic case because "he had put it in the servant's power to mismanage the carriage." Florida seems to be the only jurisdiction in which a car owner is held generally liable for the negligent operation of his dangerous instrumentality. Southern Cotton Oil Co. v. Anderson, $80 \mathrm{Fla}$. 441, 86 So. 629 (1920); Lynch v. Walker, 159 Fla. 268, 31 So. (2d) 268 (1947).

${ }^{83}$ See Harper and Kime, The Duty to Control the Conduct of Another, 43 YaLE L. J. 886, 888 et seq. (1934).

84 See e.g. Lattin, Vicarious Liability and Family Automobile, 26 MrcH. L. REv, 846 (1928). But cf. Restatearent, Agency \& 238 (1933), rejecting the doctrine. As to the possible extension of the doctrine to things other than automobiles, see Notes, 16 Mnv. L. REv. 870 (1932); 6 So. CAL. L. REv. 340 (1933).

95 See Prosser, TorTs 500. The owner has even been held liable for an accident negligently caused by his minor son's guest. Cohen v. Whiteman, 75 Ga. App. 286, 43 S. E. (2d) 184 (1947).

${ }^{08}$ See Prosser, TORTS 501.

97 See Prosser, Torts 504.

${ }^{98}$ See supra § 19.

${ }^{99}$ See Horack, The Dangerous Instrument Doctrine, 26 YaIE L. J. 224 (1916); Note, Motor Cars as Dangerous Things, Opportunity of Inspection, 3 MODERN L. REv. 235 (1940);
} 
of the owner's liability for negligence without fault would give the injured party the choice between a complaint claiming only, and limited to, damages for typical harm and one claiming damages for foreseeable harm based on the defendant's moral negligence committed by entrusting the car to an unfit person.

[\$21.] (c.) "Immune" entrepreneurs. (1) The limitation of government immunity ${ }^{100}$ is still based on distinctions about which little can be said "except that they exist, and that they are highly artificial." "It has come to be generally recognized that the usual criteria of "governmental," in contrast to "proprietary," activities do not coincide with the underlying economic test as to whether and when it is more appropriate to charge "losses typically caused by a hazardous governmental activity to the beneficiaries of that activity or to the taxpayer.

Perhaps some clarity can be brouglit into what has been called "the most hopelessly confused subject of the law"102 by approaching the thought originally underlying the immunity rule with the terminology here proposed. That "the King can do no wrong" is still true. There is no need and no way to admonish him by the threat of liability. But this rule does not preclude the King's compensatory liability for a "negligence" or "nuisance" which is not "really" a wrong but merely the basis, only historically explamable, for a liability for negligence without fault aimed at the distribution of calculable loss. Limitation of this liability to harm typically caused by the hazardous activity would permit both legislators and judges to deny immunity where full liability under the foreseeability test would place an inequitable burden on government funds or procure an unjustifiable windfall to the injured party.

Under this theory sucl activities as the supplying of water, gas, and electricity, the construction of highways or the operation of vehicles ${ }^{103}$ would clearly subject the defendant municipality to liability for harm typically caused by such activities with or without the occurrence of a moral fault. This would apply to any activity which, being hazardous, would itself entail negligence liability were it not for its toleration and

Seavey, supra note 6, at 454; Patterson, Required Motor Vehicle Insurance in New York, 18 J. Asr. INs. No. 8, pp. 13, 14 (1941). Regarding proposed legislation see Socíté DEs NAIIONS, op. cit. supra note 81 , at 8,30 ; UNLFICATION etc., op. cit. supra note 81 , at $19,31,36$. 100 See supre $\$ 16$.

101 Prosser, TORTS 1074.

102 Van Dusen, Municipactites and the Law IN Action 173 (1943) with regard to a problem of labor law.

${ }^{103}$ See e.g. City Council of Augusta v. Lombard, 99 Ga. 282, 25 S. E. 772 (1896) (water); Brantman v. Canby, 119 Minn. 396, 138 N. W. 671 (1912) (gas); Poset v. North Birmingham, 154 Ala. 511, 45 So. 663 (1907) (electricity); Engelking v. Spokane, 59 Wash. 446, 110 Pac. 25 (1910) (highway); Knauth, Government Liability for Aircraft Damage, 37 Irr. L. REv. 359 (1943) (aircraft). 
encouragement because of its preponderant social value. Where this factor is absent, as in many of the frequent cases involving recreational facilities, ${ }^{104}$ the plaintiff would be without a remedy except possibly where he has paid a consideration. ${ }^{105}$ Immunity even against liability for negligence without fault could be maintained without inconsistency for those activities which in a narrower sense may be called "governmental," such as the exercise of judicial or legislative discretion or the operation of a police force. ${ }^{106}$

Predicating governmental liability on the insurability of the harm caused would explain those seemingly anomalous decisions in which immunity was denied because of the existence of liability insurance. ${ }^{107}$ The taking of such insurance would probably be facilitated by the exclusion from that liability of potentially unimited claims for "foreseeable" harm.

(2) Similar considerations apply to the immunity of charities which, owing its origin to accident ${ }^{108}$ and devoid of a valid rationalization, ${ }^{100}$ has been recognized as untenable at this time when, in Justice Rutledge's words, "much of modern charity or philanthropy is 'big business' in its field." "110 Indeed where liability insurance is available, the immunity rule cannot even be justified by the tenuous argument opposing the diversion of trust funds. ${ }^{111}$ It can only be hoped that those still isolated decisions which deny immunity where such a fund is protected by insurance, ${ }^{112}$ will soon be good law. This development could be promoted by limiting the tort hability of charitable enterprises to harm typically caused by hazardous activities.

(3) The related problem of the tort liability of trusts seems closer to a solution in the sense here proposed. Here as in the case of charity and government activities the plaintiff's limitation to a recovery against the

104 See e.g. Stuver v. Auburn, 171 Wash. 76, 17 P. (2d) 614 (1932) (merry-go-round); Royston v. Charlotte, 278 Mich. 255, 270 N. W. 288 (1936) (swing).

${ }^{105}$ See Rome v. L. \& L. Indemn. Co., 181 La. 630, 160 So. 121 (1935); Prosser, Torts 1071.

106 See e.g. Lamont v. Stavanaugh, 129 Minn. 321, 152 N. E. 720 (1915); Rhodes v. Kansas City, 167 Kan. 719, 208 P. (2d) 275 (1949); 6 McQunIIN, THE LAw of Munictpax Corporations $\S 2802$ (2d ed. 1937, Supp. 1947). The preservation of governmental immunity regarding those activities the continuation of which could be endangered by a false claim racket, would have to be left to lagislation. The formula here proposed cannot solve this policy question any better than the present classification.

107 See supra Part I, note 93.

108 See President and Dir. of Georgetown College v. Hughes, 130 F. (2d) 810, at 815

(D. C. 1942) with historical references.

109 See Part I, § 6.

110 President and Dir. of Georgetown College v. Hughes, supra note 108, at 824.

111 See Part I, \& 6.

112 See supra Part I, note 98. 
immediate actor (public official, employee of charity, or trustee), has been found unsatisfactory where harm is caused by a hazardous enterprise activity. All too often the defendant proves financially irresponsible and a windfall would accrue to what has now often become a profit-making enterprise.

The first shift of the risk occurred when the trustee was given a right to indemnity against the trust estate in cases of strict liability ${ }^{113} \mathrm{~A}$ further step was the granting, in such cases, of a direct remedy to the injured against the estate, ${ }^{114}$ coupled, more recently, with the limitation of the trustee's liability according to the scope of his recovery from the estate. ${ }^{115}$

Though the application of this rule to all cases of tort liability lias been strongly advocated, ${ }^{116}$ the injured suing in negligence is still limited to his remedy against the trustee. But a new and highly significant development is foreshadowed in Sections 13 and 14 of the Uniform Trusts Act, wlich so far has been adopted in Louisiana, Nevada, North Carolina, Oklahoma, and South Dakota. Under those provisions a person injured by any tort committed by the trustee in the administration of the trust may sue the estate (and the trustee if paying sucli claim may sue the estate for reimbursement), (1) if the tort was a "common incident" of the kind of business activity in which the trustee was properly engaged for the trust, and (2) in any other case in which neither he nor his officers or employees were "guilty of personal fault in incurring the hability."

It is submitted that the Uniform Trusts Act is the first statute in which the existence of two different types of liability within the common law rule of "negligence" is expressly recognized: (1) a liability for harm typically caused (as a "common incident") by an enterprise, shifted from the immediate actor to a profiting and calculating entrepreneur; (2) that individual's liability for "personal fault." Several corrections, however, seem necessary in the light of the theory here proposed.

It has been pointed out that the Act by giving the trustee a right to reimbursement even in cases of personal fault (where his tort was a common incident of the enterprise) lias created a new injustice though removing one case of injustice from the law. ${ }^{117}$ Moreover, absence of personal fault is made a sufficient basis of enterprise liability even if the trustee's tort was not a "common incident" of the enterprise. It is submitted that personal fault in this connection slrould be understood as that type of negligence of which-in the draftsman's words- "ordinary business men"

113 Bennett v. Wyndham, 4 De G. F. \& J. 259, 45 Eng. Rep. 1183 (Ch. 1862).

114 In re Raybould, 1 Ch. 199 (1900).

115 Smith v. Rizzuto, 133 Neb. 655, 660, 276 N. W. 406, 409 (1937).

110 Fulda and Pond, Tort Liability of Trust Estates, 41 Cor. L. Rev. 1332, 1356 (1941).

117 Id. at 1350 et seq. 
are occasionally guilty "in the operation of any business;"118 in other words, we should exclude cases of moral negligence from the operation of the rule besides limiting it to common incidents of the enterprise. The use of the term "personal fault" for negligence both with and without fault causes an unnecessary difficulty.

Another flaw in the wording of the statute is the inclusion in "personal fault" of a servant's tort. If the trustee-master's liability, notwithstanding fault language, is strict in nature, the trustee should be permitted to recover from the estate wherever lie is held liable for his servant whether or not the latter committed a "personal fault."

Rephrased in terms of a consistent theory of negligence without fault, Sections 13 and 14 of the Uniform Trusts Act would permit the injured and the trustee to recover for harm calculably caused by that enterprise against the estate wherever the "tort" was committed as a "common incident"119 of that enterprise and not caused by the trustee's moral fault. In jurisdictions which have not enacted these provisions, similar results could perhaps be reached under the common law.

[§22.] (d.) Manufacturers and distributors. Difficult as it is to prove the "negligence" of any of the entrepreneurs previously discussed, sucli proof becomes virtually impossible where a member of the consuming public attempts to localize the cause of a liannful defect in a product of the multifarious and complex processes of modern mass manufacture and distribution. Is it preferable in such a case to allocate the loss to the consumer or to an entrepreneur who, though possibly "innocent," is a link in the chain of those entrepreneurs deriving profit from hazardous activities one of which has caused the harni? Is it preferable in such a case to allocate the loss to a consumer to whom it would be an incalculable catastrophe, or to an entrepreneur who can protect himself against just that kind of loss by insurance or price computation? To pose these questions is to answer them. In fact, both judges and juries have tended to protect the consumer by devices such as the virtual elimination of the "privity" requirement of contract law or of the foreseeability test of tort law. ${ }^{120}$

But here, again, a re-formulation of the rules so adopted for purposes foreign to their origin seems imperative. The sound growth of the law is hampered when an automobile manufacturer can be held hable for harm typically caused by a defective wheel only upon a finding of the "presence of a known danger, attendant upon a known use;"121 or when a can manu-

1183 Bogert, Trusts and Trustees $\$ 734$ (1946 perm. ed.).

119 See also Pound, The End of Law as Developed in Legal Rules and Doctrines, 27 HARv. L. REv. 195, 233 (1914), distinguishing damages "incident to the undertaking." 120 See Part I, § 8.

121 MacPherson v. Buick Motor Co., 217 N. Y. 332, 111 N. E. 1050 (1916). 
facturer's hability for harm atypically caused by a can-opener can be denied only because the harm could not "reasonably be foreseen and is not within the conpass of reasonable probability."122 Limitation of the manufacturer's liability there must be. But foreseeability, proximate causation, violation of duty, or privity are poor tests, completely foreign to economic reality. Nevertheless, the traditional language of negligence liability can perhaps be preserved by recognizing that this language in this field has conie to express what has here been called a liability for negligence without fault for harm typically caused by the defendant's hazardous activity; a hability which, in Justice Traynor's words, is imposed because "the risk of injury can be insured against by the manufacturer and distributed among the public as a cost of doing business."123

The problem whether, and if so how, proof of causation by a particular defendant manufacturer or distributor can be dispensed with for the purpose of protecting the consumer, has perhaps been brought closer to a solution by a decision of the Cahfornia Supreme Court. Two members of a hunting party were held jointly liable because it was clear that one of them had negligently shot the plaintiff. ${ }^{124}$ There is no reason why the rationale of that decision, which shifts to the defendant the burden of proof in the case of alternative causation by a dangerous activity, should not be borrowed in the law of enterprise hability for allocating harm caused by a defect arising at an unidentified place in the processes of mass production and mass distribution. ${ }^{125}$ True, neither hunter would have been held by the Cahifornia court had he not been proved negligent in having fired a shot in the plaintiff's direction. But even without the identification and proof of such a neghigent act, the rationale of this case would be applicable to the products hability of manufacturers and large distributors whose hability is recognized to be based on negligence without fault. False-claim rackets could still be discouraged by adopting or maintaining strict requirements as to the proof of harm caused.

Another problem concerns the ultimate allocation of risks between the

122 Boyd v. American Can Co., 249 App. Div. 644, 292 N. X. Supp. 689 (1936).

123 Escola v. Coca-Cola Bottling Co., 24 Cal. (2d) 453, 462, 150 P. (2d) 436, 441 (1944). See also Justice Traynor's concurring opinion in Gordon v. Aztec Brewing Co., 33 Cal. (2d) 514, 523, 203 P. (2d) 522, 528 (1949). But of. Pound, Law in the Service State: Freedom versus Equality, 36 A. B. A. J. 977,981 (1950).

124 Summers v. Tice, 33 Cal. (2d) 80, 199 P. (2d) I (1948). See supra Part I, notes 124,125 .

125 Similar considerations may underlie that rule of pleading under which plaintiffs lave been permitted to sue two entrepreneur defendants in the alternative if being in doubt as to which is liable. See S. \& C. Clothing Co. v. U. S. Trucking Corp., 216 App. Div. 482,215 N. Y. Supp. 349 (1926) (merchandise lost by either trucking or warehouse company). See also Kraft v. Smith, $24 \mathrm{Cal}$. (2d) 124, 74 P. (2d) 528 (1944) (either of two plysicians negligent); and in general CLARK, Code PIEADING 393 (2d ed. 1947). 
retailer and the manufacturer. The choice seems clear where, as in the case of branded canned goods, the manufacturer takes credit for his product and can protect its integrity. There is hittle justification for holding the retailer in the absence of moral negligence where he "has no superior means of knowing the contents of the can than the purchaser." ${ }^{\prime 126}$ A statutory strict hability of the "branding seller" would work as a "lightning rod" for the retailer who would thus be relieved, without further statutory interference, of a liability which has often been criticized with much justification. ${ }^{127}$ It seems regrettable that this solution, proposed in the First Draft of a Revised Uniform Sales Act, has apparently been abandoned. ${ }^{128}$

Even where a direct remedy is available against the producer, there should perlaps be an additional liability of those distributors who, "for purposes of msurance, absorption and reduction of loss [are] ... in a position closely akin to manufacturers." ${ }^{29}$ Indeed such distributors may in many cases, as where they distribute the products of several smaller producers, be more capable of calculating and distributing the risk than the producers themselves. Perhaps this failure to segregate those situations accounts for the general preservation of the liability of distributors. A nonlegislative distinction between "large distributors" and retailers within common law rules seems all the more desirable as no constitutional way has yet been found to draw such a distinction by statute. ${ }^{130}$ Juries could probably be relied upon to exempt from liability for negligence without fault small distributors unable to calculate, and insure against, losses caused by their merchandise.

\section{[\$23.] 4. Fault and Non-Fault Negligence in the Laws of Torts and Crimes}

The present negligence language of the courts must serve both the primarily compensatory function of enterprise liability and the primarily

126 Julian v. Lauenberger, 16 Misc. 646, 38 N. Y. Supp. 1052 (1896). See also Metrcz, The Sale of Food AND DrINK 23 et seq. (1936); Products Liability, Part I, note 1 . See also the controversies between Waite [34 MICH. L. Rev. 494 (1936); 23 MINN. L. REv. 612 (1939)] and Brown [23 Minv. L. Rev. 585 (1939)]; and between Eldredge [89 U. of PA. L. REv. 306 (1941); 45 Dick. L. REv. 269 (1941)] and Farage [45 Dick. L. REv. 159, 282 (1941)]. But cf. 1 Winliston, The Law Governdng Sales of Goods at Common Law $\S 242$ (1924).

127 See Report and Second Draft, Revised UnIforar Sates Act 24 (1941); Waite, Retail Responsibility and Judicial Law Making, 34 MicH. L. Rev. 494 (1936).

128 Compare the mimeographed First Draft (1940) with the Report and Second Draft of the Revised UnIforar SaLes Act (1941); and in general, Products Liability, Part I, note 1 , at $\S 38$.

129 Report and Second Draft, Revised UnIforar SAIES ACT 124 (1941).

130Id. at 116. The proposed liability scheme would necessitate the broadening of the retailer's insurance protection [see LANGE, AdDress, Convention of National Retail Dry Goods Association (1939) 2, 10], and the substitution of direct coverage for the present coverage by "certificates" on the producer's policy. [See Perryman in CAmmL, Products Linbiritx InsURANCE, 21 Proceedings Cas. Act. Sec., Nos. 43, 44 (1935)]. 
admonitory function of the original liability for fault. This fact has not only been detrimental to the development of enterprise liability but has equally affected those other types of negligence liability which, iniplying blame, may appropriately be called liabilities for "moral" negligence. ${ }^{131}$

The distinction here proposed can, I believe, aid in the clarification of both types of hability. ${ }^{132}$ But "moral" negligence and negligence without fault do not occupy the whole field of whit is now referred to as "negligence." There remains the liability for "objective" negligence not connected with the hazards of modern enterprise, which seems to defy classification. For, on the one hand, that objective negligence can liardly be called "moral," since it is determined by a fictitious foreseeability test similar to that of negligence without fault and strict liability. ${ }^{133}$ On the other hand, objective negligence, with its strong undercurrent of censure in language and ideology, ${ }^{134}$ cannot wholly be segregated fron "nioral" negligence. The existence of this twilight zone should, however, not prevent us from a separation of the clearly separable fields of enterprise liability for negligence without fault and non-enterprise hability for "moral" negligence.

The doctrine of res ipsa loquitur, which originally facilitated proof of fault, has been forced into an "unhappy marriage" with the presumption of negligence without fault in carriers' hability. ${ }^{135}$ Once the "negligence" hability of modern enterprise has been rerationalized as a liability for negligence without fault for calculable harm, res ipsa can be relieved of the danger of being compelled to find fault where none can be found $\mathrm{d}^{136}$ and returned to its original meaning of a rule of evidence. And respondeat superior, once it is no longer needed to create a non-fault liability in fault

131 See Part I, $\S \S 10,11$. Shortcomings of the related "wilful and wanton misconduct" terminology are ably discussed by Burrell, $A$ New Approach to the Problem of Wilful and Wanton Misconduct, [1949] INs. L. J. 716 (1949).

132 See Bohlen, Old Plirases and New Facts, 83 U. of PA. L. Rev. 305, 312 (1935): "There is no reason ... why the same rules should apply where the responsibility is based, in theory at least, and still too largely also in fact, on the wrongdoing of the defendant and where, as in workmen's compensation cases and insurance cases, culpability, real or legalistieally assumed, has no part in determining the existence or extent of responsibility." This prophetic "dictum" is followed by the exhortation directed to the courts to explain openly the "real reasons for their decisions."

133 See supra §§ 13-16.

134 This undercurrent is apparent in the usual formulation of the objective negligence rule in terms of "one must ..." [see e.g., HorMEs, THE COMMON LAW 108 (1881)] or in the exceptional treatment of super- or sub-normal injurers who, under a consistent "objective" theory, would not be judged according to their superior or inferior knowledge or ability. But see Seavey, Negligence-Subjective or Objective, 41 HARv. L. Rev. 1 (1927); Restatement, Torts $\$ \S 283,289$ Comment (n) (1934); Edgerton, supra note 57, 857.

135 See Part I, \& 5 .

${ }^{136}$ See Part I, notes 30, 127 . 
language, could develop a policy justifying that language by a return to the selection and control idea of its early stages. ${ }^{137}$

Once moral negligence is no longer the basis of the distribution of risks innocently incurred and can again be defined as blameworthy conduct, it may again become usable in criminal law which should punish only the conscious creation of risk. ${ }^{138}$ Whether or not criminal negligence should be identified with, or even related to, tort negligence, is beyond the scope of this study. ${ }^{130}$ But that relation exists and has resulted in a hardly desirable intrusion into criminal law of the trend in tort law to base a compensatory liability on fault language. ${ }^{140}$ In order to hold a railroad liable in tort for the death caused by a switchman who had misread a time table, or to hold a construction corporation for the death caused by a laborer who used too much powder in a blasting operation, ${ }^{141}$ a jury would have to find negligence in inadvertence. That employees lave in such cases occasionally been convicted of manslaughter may be attributable to the similar tour de force in the development of enterprise liability. Once civil law sanctions for the causation of calculable liarm protect the injured without regard to the defendant's responsibility for the foreseeability of that harm, punishment adequate to the moral fault committed, that is, to that foreseeability, can become the rule in criminal law. ${ }^{142}$

To sum up: The negligence rule, thougll phrased in terms of fault, has, with regard to tort liabilities for dangerous enterprise, come to exercise a function of loss distribution previously developed mainly within rules of strict liability. This new function of "fault" liability las transformed its

137 See Part I, \& 3.

${ }^{138}$ See Wechsler-Michael, A Rationale of the Law of Homicide, 37 Cor. L. REv. 701, 721 (1937).

${ }^{139}$ See Kirchheimer, Criminal Omissions, 55 Harv. L. Rev. 615 (1942); Harr, PrnsCIPIes of Crinmal Law 215 (1947); Prosser, Torts 10 et seq.; Hitschler, Crimes and Civil Injuries, 39 DICr. L. Rev. 23 (1934). Regarding the related problem of the prejudiciality in tort proceedings of criminal convictions see e.g. Note, Criminal Judgments as Res Adjudicata in Civil Actions for Penalties, 11 CoL. L. REv. 170 (1911); NEW YORK LAW Revision Comanasstox, Report (1939) 391 et seq.; Von Moschzisker, Res Judicata, 38 YaLE L. J. 299, 325 (1929); Schumdi, Faute Civine et Faute Pénale (1928) 71 et seq., 125 et seq.

140 No opinion is expressed as to whether the present trend towards objectivation in the criminal law itself has been promoted by parallel trends in the law of torts. See Sayre, The Present Significance of Mens Rea in the Criminal Law, Harvard Legar Essays 399 (1934). Holmes, J., in Commonwealth v. Pierce, 138 Mass. 165, 52 Am. Rep. 264 (1884) expressly invokes the law of torts for justifying the promotion of external standards in the law of crimes "in the interest of the safety of all." Regarding legislative and judicial attempts at introducing "Criminal Linbility of a Business Man for Conduct of his Employees," see Note, 38 J. Crmar. Law and Crtactrotogy 132 (1947).

141 Regina v. Benge, 4 F. \& F. 504, 176 Eng. Rep. 665 (1865); People v. Clemente, 146 App. Div. 109, 130 N. Y. Supp. 612 (1911). 142 See Note, 31 CALIF. L. REv. 215 (1943). 
central concepts of reprehensible conduct and "foreseeability" of harm in a way foreign to its language and original rationale and has thus produced in our present "negligence" language a series of misleading equivocations.

While neither statutory nor judicial legislation can or should attempt a wholesale reform of the well-estabhshed system of negligence hability, I believe that either statutory or judicial interpretation should recognize and resolve these equivocations, which hamper the natural growth of judicial as well as statutory law by concealing essential distinctions between the original field of negligence liability and the liability for "negligence without fault" of modern enterprise. Such recoginition would, among other things, facilitate imtelligent and intelligible instructions to the jury by limiting the present "foreseeability" test to harm caused by reprehensible conduct and by substituting for that test one of typicality with regard to harm caused by the lawful activities of hazardous enterprise.

Whether a man carelessly slooting at birds in a village street is to be held for injuries inflicted upon a bystander by a falling bird, should be determined according to whether a reasonable man in the defendant's place could have foreseen such injuries. But whether a railroad company is to be held for the drowning of four children chasing a kite across a frozen pond formed by the inadvertence of a railroad employee, ${ }^{143}$ should be determined according to whether such result was typical for the hazards of the operation of a railroad and thus reasonably insurable. True, doubts will remain and this theory will not, any more than any other theory, resolve all problems. But one merit the author feels he can claim for his formulation of the negligence rule as applied to enterprise liability: juries and judges would no longer be misled by "horse and buggy rules in an age of machinery."144

143 See Part I, § 1.

144 James, Accident Liability Reconsidered: The Impact of Liability Insurance, 57 YarE L. J. 549, 569 (1948). 